\title{
REVIEW
}

\section{Impacts of introduced mammalian predators on New Zealand's alpine fauna}

\author{
Colin F. J. O’Donnel1 ${ }^{1}$, Kerry A. Weston ${ }^{1 *}$ and Joanne M. Monks ${ }^{2}$ \\ ${ }^{1}$ Science and Policy Group, Department of Conservation, Private Bag 4715, Christchurch Mail Centre, Christchurch 8140 , \\ New Zealand \\ ${ }^{2}$ Science and Policy Group, Department of Conservation, PO Box 5244, Dunedin 9058, New Zealand \\ *Author for correspondence (Email: kweston@doc.govt.nz)
}

Published online: 9 December 2016

\begin{abstract}
Alpine zones are threatened globally by invasive species, hunting, and habitat loss caused by fire, anthropogenic development and climate change. These global threats are pertinent in New Zealand, with the least understood pressure being the potential impacts of introduced mammalian predators, the focus of this review. In New Zealand, alpine zones include an extensive suite of cold climate ecosystems covering c. $11 \%$ of the land mass. They support rich communities of indigenous invertebrates, lizards, fish, and birds. Many taxa are obligate alpine dwellers, though there is uncertainty about the extent to which distributions of some species are relicts of wider historical ranges. The impacts of introduced mammalian predators are well described in many New Zealand ecosystems, though little is known about the impacts of these predators on alpine fauna. Here we review the importance of alpine habitats for indigenous fauna and the impacts of introduced mammalian predators; and develop a conceptual model explaining threat interactions. Most evidence for predation is anecdotal or comes from studies of species with wider ranges and at lower altitudes. Nevertheless, at least ten introduced predator species have been confirmed as frequent predators of native alpine species, particularly among birds and invertebrates. In the case of the endangered takahe (Porphyrio hochstetteri) and rock wren (Xenicus gilviventris), stoats (Mustela erminea) are primary predators, which are likely to be impacting significantly on population viability. We also document records of mammalian predation on alpine lizards and freshwater fish. While the precise impacts on the long-term viability of threatened species have not been evaluated, anecdotal evidence suggests that predation by mammals is a serious threat, warranting predator control. Future research should focus on predicting when and where mammalian predators impact on populations of indigenous fauna, furthering our understanding of the alpine predator guild particularly through adaptive management experiments, and exploring interactions with other threats.
\end{abstract}

Keywords: alpine; conceptual model; mast seeding; mustelids; possums; predation; rock wren; rodents; threatened species; weasels

\section{Introduction}

Alpine environments and many of the specialist species that inhabit these zones are threatened globally (Franzén \& Molander 2012; Scridel 2014). The alpine zone can be broadly defined as the altitudinal area above the climatic timberline (or equivalent elevations in non-forested environments) (Mark \& Dickinson 1997; Mark et al. 2000). Alpine ecosystems are challenging environments for plants and animals, and their inhabitants display a range of physiological and behavioural adaptations to this environment. For example, some animals display greater longevity, relatively large body sizes (Scridel 2014) and physiological advantages such as high-elevation haemoglobin genotypes (Dragon et al. 1999) or the ability to survive freezing (Ramløv et al. 1996). Alpine species are subject to a large number of constraints imposed by extremely low temperatures - hypoxia, long and variable periods of snow and ice loading, and limited food availability (Sandercock et al. 2005; Scridel 2014). Such characteristics lead to shortened breeding seasons and relatively low fecundity, and exacerbate the vulnerability of alpine species to anthropogenic threats.

Alpine habitats and their specialised biodiversity are threatened by a wide range of factors including browsing, predation (MacDonald \& Bolton 2008), hunting (Sandercock et al. 2005) and habitat loss through land use changes (Laiolo et al. 2004), anthropogenic development (Rolando et al. 2007; Patthey et al. 2008), fire, and the emerging threat of climate change (Dirnböck et al. 2011; Chamberlain et al. 2013). Northern Hemisphere climate models generally predict massive contraction in the ranges of some alpine bird species, and elevational shifts in habitats for a wide range of taxonomic groups (Chen et al. 2011; Dirnböck et al. 2011).

In New Zealand, alpine areas form one of the most widespread environments (c. 11\% of the land area; Fig. 1). They encompass an altitudinal belt of c. $1000 \mathrm{~m}$ over much of the country that is generally subdivided into low-alpine and high-alpine zones, each with their own vegetation communities; and above this belt is the nival zone, which is characterised by permanent snow, ice and rock (Mark \& Dickinson 1997; Mark et al. 2000). These zones are altitudinally compressed at higher latitudes (e.g. an altitudinal belt of c. $500 \mathrm{~m}$ on Stewart Island). Tall tussock grasslands dominated by one or more species of the genus Chionochloa characterise the low-alpine zone (Connor 1991), with shrubs and large herbs often co-dominating within c. $200 \mathrm{~m}$ of the timberline (Mark et al. 2000). Above the upper altitudinal limit of the low 


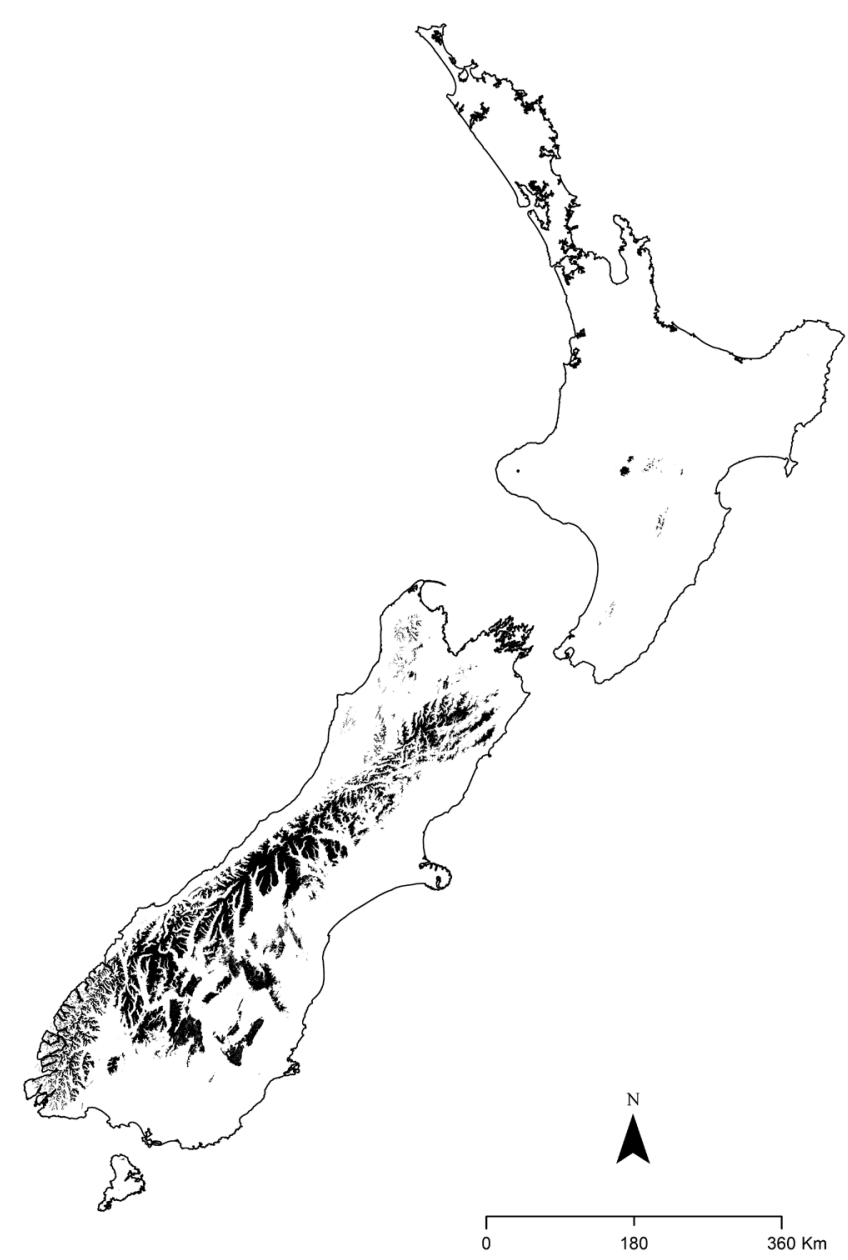

Figure 1. Estimated extent of the New Zealand alpine zones using ArcGIS for Desktop Spatial Analysis Tools. Spatial extent was estimated by creating a minimum height raster based broadly on a regression in treeline altitude of $-100 \mathrm{~m}$ elevation for every degree in latitude southwards, starting at 2100 m.a.s.l. at the northern tip of the North Island (Cieraad \& McGlone 2014). A 25 metre digital elevation model (DEM) provided by Landcare Research $\mathrm{NZ}$ with the minimum height raster was then overlaid to find all areas where the DEM value was above the minimum height value. The resulting area was extracted to a polygon, extracting the following land cover areas provided from the NZ Land Cover Database (LCDB v 4.1): Permanent snow and ice, gravel or rock, landslide, alpine grass/herbfield, sub alpine shrubland, and tall tussock grassland.

alpine zone, tall tussock species give way to shorter grasses, dwarf shrubs and cushion or turf-forming herbs in fellfields; growth forms indicative of the high alpine zone (Mark \& Dickinson 1997). As a consequence of relatively recent rapid tectonic activity and glaciations, phylogenetic radiations of plants and animals have been extensive in the alpine zone, especially among plant and invertebrate communities, but including reptiles and birds (Wallis \& Trewick 2009). Floral diversity throughout the alpine zone is high, with $>600$ species of vascular alpine plants, the majority of which (c. 93\%) are endemic (Mark \& Adams 1995).

Global threats to alpine ecosystems are also pertinent in New Zealand, particularly the effects of invasive browsers and predators, climate change, and to a lesser extent, fire and anthropogenic development (e.g. ski resorts, wind farms). Introduced mammalian herbivores, particularly Himalayan
tahr(Hemitragusjemlahicus), chamois (Rupicapra rupicapra), red deer (Cervus elephas), brushtail possums (Trichosurus vulpecula) and hares (Lepus europaeus) browse a wide variety of alpine plants, usually with each species feeding primarily on particular plant species or groups of species. Goats (Capra hircus), high country sheep and other ungulates contribute locally to browsing pressure in some places. However, the absolute impacts of browsers on alpine plant species and regeneration remains uncertain (Flux 1967; Lavers et al. 1983; Rose \& Platt 1987, 1992; Wong \& Hickling 1999; Hickling \& Forsyth 2000; Parkes \& Forsyth 2008) and identifying them is complicated by the extinction of many indigenous avian browsers (Holdaway 1989; Horrocks et al. 2004; Lee et al. 2010; Wood et al. 2012). The impacts of climate change in the alpine zone are likely to revolve around changes in habitat suitability, seasonality of food sources, changes in both indigenous and introduced species abundance, increased fire frequency, and potentially new diseases and pathogens (Christie 2014). Many pests that currently have upper altitudinal limits are likely to extend to higher elevations under predicted warming (Christie 2014).

At least 13 species of introduced mammals have been recorded as significant predators of indigenous threatened wildlife across a range of taxonomic groups in forest, river, coastal and wetland habitats (Ramsay 1978; Dowding \& Murphy 2001; Sanders \& Maloney 2002; Baker 2006; Innes et al. 2010; Reardon et al. 2012; O’Donnell et al. 2015). In alpine areas, there is little understanding of the potential impacts of these predators, despite their presence there (Wilson et al. 2006; Smith et al. 2007). Understanding these factors is important, because there may be a need to control predators in alpine areas if vulnerable indigenous taxa are to persist, just as is done in other ecosystems in New Zealand (Baber et al. 2009; O'Donnell \& Hoare 2012; Reardon et al. 2012; Cruz et al. 2013). We focus this review on indigenous fauna that characteristically feed, shelter and/or breed in the alpine zone, but exclude species that are merely vagrants to alpine habitats. The objectives of this review are to: (1) describe the significance of alpine faunal communities in New Zealand; (2) examine the anecdotal and published evidence for predation by introduced mammalian predators on fauna characteristic of the alpine zone; (3) summarise information on the presence and abundance of mammalian predators in alpine areas and factors that drive predation risk; and (4) indicate future directions for research and conservation management, on the basis of a conceptual ecological model.

\section{Value of alpine habitats for indigenous fauna}

\section{Birds}

We record 24 indigenous bird species as characteristic of the alpine bird community, of which 17 are threatened or at risk (Table 1; Robertson et al. 2013). A species can be categorised as restricted to the alpine zone for at least part of its life history (obligate user), as living in a range of lowland, montane and alpine habitats of which the alpine zone is an important habitat (primary user), or present incidentally or locally in the alpine zone but not dependent on alpine habitat (facultative user). Only three species are obligate users of the alpine zone (i.e. restricted to it for at least part of their life history): Hutton's shearwaters (Puffinus huttoni), takahēe(Porphyrio hochstetteri) and rock wrens (Xenicus gilviventris). Hutton's shearwaters 
Table 1. Characteristic indigenous vertebrate fauna of the New Zealand alpine zone

\begin{tabular}{|c|c|c|c|c|c|c|c|}
\hline Common name & Scientific name & Threat status $^{1}$ & $\begin{array}{l}\text { Dependence on } \\
\text { alpine zone }\end{array}$ & $\mathrm{Use}^{3}$ & $\begin{array}{l}\text { Mammalian } \\
\text { predation in } \\
\text { alpine habitat } \\
\text { confirmed }^{4}\end{array}$ & $\begin{array}{l}\text { Mammalian } \\
\text { predation in } \\
\text { non-alpine } \\
\text { habitats } \\
\text { confirmed }^{5}\end{array}$ & $\begin{array}{l}\text { Alpine } \\
\text { distribution }\end{array}$ \\
\hline \multicolumn{8}{|l|}{ Birds } \\
\hline Haast tokoeka & $\begin{array}{l}\text { Apteryx australis } \\
\text { "Haast" }\end{array}$ & $\begin{array}{l}\text { Nationally } \\
\text { critical }\end{array}$ & Primary & $\mathrm{F}, \mathrm{B}, \mathrm{S}$ & Yes & Yes & Haast Range \\
\hline Great spotted kiwi & Apteryx haastii & $\begin{array}{l}\text { Nationally } \\
\text { vulnerable }\end{array}$ & Primary & $\mathrm{F}, \mathrm{B}, \mathrm{S}$ & & Yes & $\begin{array}{l}\text { North of Arthurs } \\
\text { Pass, South Island } \\
\text { only }\end{array}$ \\
\hline Fiordland tokoeka & $\begin{array}{l}\text { Apteryx a. } \\
\text { australis }\end{array}$ & $\begin{array}{l}\text { Nationally } \\
\text { vulnerable }\end{array}$ & Primary & $\mathrm{F}, \mathrm{S}$ & Yes & Yes & $\begin{array}{l}\text { Fiordland } \\
\text { mountains }\end{array}$ \\
\hline $\begin{array}{l}\text { Hutton's } \\
\text { shearwater }\end{array}$ & Puffinus huttoni & Declining & Obligate & $\mathrm{B}$ & Yes & & $\begin{array}{l}\text { Seaward } \\
\text { Kaikoura Range }\end{array}$ \\
\hline Black shag & $\begin{array}{l}\text { Phalacrocorax } \\
\text { carbo }\end{array}$ & Declining & Facultative & $\mathrm{F}$ & & & $\begin{array}{l}\text { Tarns and } \\
\text { streams, throughout }\end{array}$ \\
\hline Paradise shelduck & Tadorna variegata & Not threatened & Facultative & $\mathrm{F}, \mathrm{S}$ & & Yes & $\begin{array}{l}\text { Tarns and } \\
\text { streams, throughout }\end{array}$ \\
\hline Whio & $\begin{array}{l}\text { Hymenolaimus } \\
\text { malacorhynchos }\end{array}$ & $\begin{array}{l}\text { Nationally } \\
\text { vulnerable }\end{array}$ & Facultative & $\mathrm{F}, \mathrm{B}, \mathrm{S}$ & & Yes & $\begin{array}{l}\text { Alpine streams } \\
\text { throughout }\end{array}$ \\
\hline Grey duck & Anas superciliosa & Nationally critical & Facultative & $\mathrm{F}, \mathrm{B}, \mathrm{S}$ & & Yes & $\begin{array}{l}\text { Tarns and } \\
\text { streams, throughout }\end{array}$ \\
\hline NZ scaup & $\begin{array}{l}\text { Aythya } \\
\text { novaeseelandiae }\end{array}$ & Not threatened & Facultative & $\mathrm{F}, \mathrm{B}, \mathrm{S}$ & & Yes & Throughout \\
\hline $\begin{array}{l}\text { Australasian } \\
\text { harrier }\end{array}$ & $\begin{array}{l}\text { Circus } \\
\text { approximans }\end{array}$ & Not threatened & Facultative & $\mathrm{F}, \mathrm{B}, \mathrm{S}$ & & & Throughout \\
\hline NZ falcon & $\begin{array}{l}\text { Falco } \\
\text { novaeseelandiae }\end{array}$ & $\begin{array}{l}\text { Nationally } \\
\text { vulnerable }\end{array}$ & Primary & $\mathrm{F}, \mathrm{B}, \mathrm{S}$ & & & Throughout \\
\hline Western weka & $\begin{array}{l}\text { Gallirallus a. } \\
\text { australis }\end{array}$ & Not threatened & Primary & $\mathrm{F}, \mathrm{B}, \mathrm{S}$ & & Yes & $\begin{array}{l}\text { Fiordland, } \\
\text { northern South } \\
\text { Island }\end{array}$ \\
\hline Takahē & $\begin{array}{l}\text { Porphyrio } \\
\text { hochstetteri }\end{array}$ & Nationally critical & Obligate, relict & $\mathrm{F}, \mathrm{B}, \mathrm{S}$ & Yes & & Fiordland \\
\hline $\begin{array}{l}\text { Southern New } \\
\text { Zealand dotterel }\end{array}$ & $\begin{array}{l}\text { Charadrius o. } \\
\text { obscurus }\end{array}$ & Nationally critical & Primary, relict & $\mathrm{F}, \mathrm{B}, \mathrm{S}$ & Yes & & Stewart Island \\
\hline Banded dotterel & $\begin{array}{l}\text { Charadrius } \\
\text { bicinctus }\end{array}$ & $\begin{array}{l}\text { Nationally } \\
\text { vulnerable }\end{array}$ & Primary & $\mathrm{F}, \mathrm{B}, \mathrm{S}$ & & Yes & $\begin{array}{l}\text { Canterbury, } \\
\text { Otago, Stewart } \\
\text { Island }\end{array}$ \\
\hline $\begin{array}{l}\text { Southern } \\
\text { black-backed gull }\end{array}$ & Larus dominicanus & Not threatened & Primary & $\mathrm{F}, \mathrm{B}, \mathrm{S}$ & & & Throughout \\
\hline Black-fronted tern & $\begin{array}{l}\text { Chlidonias } \\
\text { albostriatus }\end{array}$ & $\begin{array}{l}\text { Nationally } \\
\text { endangered }\end{array}$ & Facultative & $\mathrm{F}, \mathrm{B}$, & & Yes & $\begin{array}{l}\text { South Island } \\
\text { mountains }\end{array}$ \\
\hline Kea & Nestor notabilis & $\begin{array}{l}\text { Nationally } \\
\text { endangered }\end{array}$ & Primary & $\mathrm{F}, \mathrm{B}, \mathrm{S}$ & Yes & Yes & $\begin{array}{l}\text { South Island } \\
\text { mountains }\end{array}$ \\
\hline Kākā & Nestor meridionalis & $\begin{array}{l}\text { Nationally } \\
\text { vulnerable }\end{array}$ & Facultative & $\mathrm{F}$ & & Yes & Throughout \\
\hline Silvereye & Zosterops lateralis & Not threatened & Primary & $\mathrm{F}$ & & Yes & Throughout \\
\hline Rock wren & Xenicus gilviventris & $\begin{array}{l}\text { Nationally } \\
\text { endangered }\end{array}$ & Obligate & $\mathrm{F}, \mathrm{B}, \mathrm{S}$ & Yes & & $\begin{array}{l}\text { South Island } \\
\text { mountains }\end{array}$ \\
\hline NZ pipit & $\begin{array}{l}\text { Anthus } \\
\text { novaeseelandiae }\end{array}$ & Declining & Primary & $\mathrm{F}, \mathrm{B}, \mathrm{S}$ & & Yes & Throughout \\
\hline Fernbird & Bowdleria punctata & Declining & Primary & $\mathrm{F}, \mathrm{B}, \mathrm{S}$ & & Yes & $\begin{array}{l}\text { Otago, } \\
\text { Canterbury, } \\
\text { northern South } \\
\text { Island }\end{array}$ \\
\hline Tomtit & $\begin{array}{l}\text { Petroica } \\
\text { macrocephala }\end{array}$ & Not threatened & Primary & $\mathrm{F}, \mathrm{B}, \mathrm{S}$ & & Yes & Throughout \\
\hline \multicolumn{8}{|l|}{ Lizards } \\
\hline Cascade gecko & $\begin{array}{l}\text { Mokopirirakau } \\
\text { "Cascades" }\end{array}$ & Declining & Primary & $\mathrm{F}, \mathrm{B}, \mathrm{S}$ & Yes & & $\begin{array}{l}\text { South Westland, } \\
\text { Fiordland }\end{array}$ \\
\hline $\begin{array}{l}\text { Cupola Basin } \\
\text { gecko }\end{array}$ & $\begin{array}{l}\text { Mokopirirakau } \\
\text { "Cupola" }\end{array}$ & Data deficient & Obligate, relict? & $\mathrm{F}, \mathrm{B}, \mathrm{S}$ & & & Nelson Lakes \\
\hline
\end{tabular}




\begin{tabular}{|c|c|c|c|c|c|c|c|}
\hline Common name & Scientific name & Threat status $^{1}$ & $\begin{array}{l}\text { Dependence on } \\
\text { alpine zone } e^{2}\end{array}$ & $\mathrm{Use}^{3}$ & $\begin{array}{l}\text { Mammalian } \\
\text { predation in } \\
\text { alpine habitat } \\
\text { confirmed }^{4}\end{array}$ & $\begin{array}{l}\text { Mammalian } \\
\text { predation in } \\
\text { non-alpine } \\
\text { habitats } \\
\text { confirmed }^{5}\end{array}$ & $\begin{array}{l}\text { Alpine } \\
\text { distribution }\end{array}$ \\
\hline $\begin{array}{l}\text { Orange spotted } \\
\text { gecko }\end{array}$ & $\begin{array}{l}\text { Mokopirirakau } \\
\text { "Roys Peak" }\end{array}$ & $\begin{array}{l}\text { Nationally } \\
\text { vulnerable }\end{array}$ & Primary & $\mathrm{F}, \mathrm{B}, \mathrm{S}$ & & & Otago \\
\hline Takitimu gecko & $\begin{array}{l}\text { Mokopirirakau } \\
\text { cryptozoicus }\end{array}$ & $\begin{array}{l}\text { Nationally } \\
\text { vulnerable }\end{array}$ & Primary & $\mathrm{F}, \mathrm{B}, \mathrm{S}$ & & & Southland \\
\hline Forest gecko & $\begin{array}{l}\text { Mokopirirakau } \\
\text { granulatus }\end{array}$ & Declining & Facultative & $\mathrm{F}, \mathrm{B}, \mathrm{S}$ & & & $\begin{array}{l}\text { Mount Taranaki } \\
\text {-Lewis Pass }\end{array}$ \\
\hline Black-eyed gecko & $\begin{array}{l}\text { Mokopirirakau } \\
\text { kahutarae }\end{array}$ & $\begin{array}{l}\text { Nationally } \\
\text { vulnerable }\end{array}$ & Obligate, relict? & $\mathrm{F}, \mathrm{B}, \mathrm{S}$ & & & $\begin{array}{l}\text { Northern South } \\
\text { Island }\end{array}$ \\
\hline Harlequin gecko & Tukutuku rakiurae & $\begin{array}{l}\text { Nationally } \\
\text { vulnerable }\end{array}$ & Obligate, relict? & $\mathrm{F}, \mathrm{B}, \mathrm{S}$ & & & Stewart Island \\
\hline Mini mac gecko & $\begin{array}{l}\text { Woodworthia } \\
\text { "Marlborough mini" }\end{array}$ & Not threatened & Facultative & $\mathrm{F}, \mathrm{B}, \mathrm{S}$ & & & $\begin{array}{l}\text { Malborough and } \\
\text { southern North } \\
\text { Island }\end{array}$ \\
\hline Kahurangi gecko & $\begin{array}{l}\text { Woodworthia } \\
\text { "Mount Arthur" }\end{array}$ & $\begin{array}{l}\text { Naturally } \\
\text { uncommon }\end{array}$ & Obligate, relict? & $\mathrm{F}, \mathrm{B}, \mathrm{S}$ & & & Kahurangi \\
\hline Kōrero gecko & $\begin{array}{l}\text { Woodworthia } \\
\text { "Otago/Southland } \\
\text { large" }\end{array}$ & Declining & Facultative & $\mathrm{F}, \mathrm{B}, \mathrm{S}$ & & & Otago \\
\hline $\begin{array}{l}\text { Southern Alps } \\
\text { gecko }\end{array}$ & $\begin{array}{l}\text { Woodworthia } \\
\text { "Southern Alps" }\end{array}$ & Not threatened & Primary & $\mathrm{F}, \mathrm{B}, \mathrm{S}$ & & & Canterbury \\
\hline Short-toed gecko & $\begin{array}{l}\text { Woodworthia } \\
\text { "southern mini" }\end{array}$ & Not threatened & Primary & $\mathrm{F}, \mathrm{B}, \mathrm{S}$ & & & $\begin{array}{l}\text { Southern South } \\
\text { Island }\end{array}$ \\
\hline Raukawa gecko & $\begin{array}{l}\text { Woodworthia } \\
\text { maculata }\end{array}$ & Not threatened & Facultative & $\mathrm{F}, \mathrm{B}, \mathrm{S}$ & & & $\begin{array}{l}\text { North Island and } \\
\text { northern South } \\
\text { Island }\end{array}$ \\
\hline Mackenzie skink & $\begin{array}{l}\text { Oligosoma aff. } \\
\text { lineoocellatum } \\
\text { "Mackenzie } \\
\text { Basin" }\end{array}$ & $\begin{array}{l}\text { Nationally } \\
\text { vulnerable }\end{array}$ & Facultative & $\mathrm{F}, \mathrm{B}, \mathrm{S}$ & & & Canterbury \\
\hline $\begin{array}{l}\text { Canterbury spotted } \\
\text { skink }\end{array}$ & $\begin{array}{l}\text { Oligosoma aff. } \\
\text { lineoocellatum } \\
\text { "central } \\
\text { Canterbury" }\end{array}$ & $\begin{array}{l}\text { Nationally } \\
\text { vulnerable }\end{array}$ & Facultative & $\mathrm{F}, \mathrm{B}, \mathrm{S}$ & & & Canterbury \\
\hline Pukuma skink & $\begin{array}{l}\text { Oligosoma aff. } \\
\text { longipes } \\
\text { "Rangitata" }\end{array}$ & $\begin{array}{l}\text { Nationally } \\
\text { critical }\end{array}$ & Obligate, relict? & $\mathrm{F}, \mathrm{B}, \mathrm{S}$ & & & Canterbury \\
\hline $\begin{array}{l}\text { Southern long-toed } \\
\text { skink }\end{array}$ & $\begin{array}{l}\text { Oligosoma aff. } \\
\text { longipes } \\
\text { "Southern" }\end{array}$ & Declining & Facultative & $\mathrm{F}, \mathrm{B}, \mathrm{S}$ & & & Canterbury \\
\hline Cryptic skink & $\begin{array}{l}\text { Oligosoma } \\
\text { inconspicuum }\end{array}$ & Declining & Facultative & $\mathrm{F}, \mathrm{B}, \mathrm{S}$ & & & $\begin{array}{l}\text { Southern South } \\
\text { Island }\end{array}$ \\
\hline Speckled skink & $\begin{array}{l}\text { Oligosoma } \\
\text { infrapunctatum }\end{array}$ & Declining & Facultative & $\mathrm{F}, \mathrm{B}, \mathrm{S}$ & & & $\begin{array}{l}\text { North Island, } \\
\text { northern South } \\
\text { Island }\end{array}$ \\
\hline Barrier skink & Oligosoma judgei & $\begin{array}{l}\text { Nationally } \\
\text { endangered }\end{array}$ & Obligate, relict? & $\mathrm{F}, \mathrm{B}, \mathrm{S}$ & & & Fiordland \\
\hline McCann's skink & $\begin{array}{l}\text { Oligosoma } \\
\text { maccanni }\end{array}$ & Not threatened & Facultative & $\mathrm{F}, \mathrm{B}, \mathrm{S}$ & & & $\begin{array}{l}\text { Throughout South } \\
\text { Island south of } \\
\text { Lewis Pass, east } \\
\text { of divide }\end{array}$ \\
\hline Southern skink & $\begin{array}{l}\text { Oligosoma } \\
\text { notosaurus }\end{array}$ & Not threatened & Primary & $\mathrm{F}, \mathrm{B}, \mathrm{S}$ & & & Stewart Island \\
\hline Sinbad skink & $\begin{array}{l}\text { Oligosoma } \\
\text { pikitanga }\end{array}$ & $\begin{array}{l}\text { Nationally } \\
\text { endangered }\end{array}$ & Obligate, relict? & $\mathrm{F}, \mathrm{B}, \mathrm{S}$ & & & Fiordland \\
\hline $\begin{array}{l}\text { Northern grass } \\
\text { skink }\end{array}$ & $\begin{array}{l}\text { Oligosoma } \\
\text { polychroma }\end{array}$ & Not threatened & Facultative & $\mathrm{F}, \mathrm{B}, \mathrm{S}$ & & & $\begin{array}{l}\text { Mount Ruapehu, } \\
\text { north-west South } \\
\text { Island - Lewis } \\
\text { Pass }\end{array}$ \\
\hline $\begin{array}{l}\text { South } \\
\text { Marlborough skink }\end{array}$ & $\begin{array}{l}\text { Oligosoma aff. } \\
\text { polychroma } \\
\text { Clade } 3\end{array}$ & Declining & Facultative & $\mathrm{F}, \mathrm{B}, \mathrm{S}$ & & & $\begin{array}{l}\text { Inland South } \\
\text { Marlborough }\end{array}$ \\
\hline
\end{tabular}




\begin{tabular}{|c|c|c|c|c|c|c|c|}
\hline Common name & Scientific name & Threat status ${ }^{1}$ & $\begin{array}{l}\text { Dependence on } \\
\text { alpine zone }\end{array}$ & $\mathrm{Use}^{3}$ & $\begin{array}{l}\text { Mammalian } \\
\text { predation in } \\
\text { alpine habitat } \\
\text { confirmed }^{4}\end{array}$ & $\begin{array}{l}\text { Mammalian } \\
\text { predation in } \\
\text { non-alpine } \\
\text { habitats } \\
\text { confirmed }^{5}\end{array}$ & $\begin{array}{l}\text { Alpine } \\
\text { distribution }\end{array}$ \\
\hline $\begin{array}{l}\text { Canterbury grass } \\
\text { skink }\end{array}$ & $\begin{array}{l}\text { Oligosoma aff. } \\
\text { polychroma } \\
\text { Clade } 4\end{array}$ & Declining & Facultative & $\mathrm{F}, \mathrm{B}, \mathrm{S}$ & & & $\begin{array}{l}\text { Canterbury } \\
\text { foothills }\end{array}$ \\
\hline $\begin{array}{l}\text { Southern grass } \\
\text { skink }\end{array}$ & $\begin{array}{l}\text { Oligosoma aff. } \\
\text { polychroma } \\
\text { Clade } 5\end{array}$ & Declining & Facultative & $\mathrm{F}, \mathrm{B}, \mathrm{S}$ & & & $\begin{array}{l}\text { Banks Peninsula, } \\
\text { South Canterbury, } \\
\text { Otago, Fiordland }\end{array}$ \\
\hline Eyres skink & Oligosoma repens & $\begin{array}{l}\text { Nationally } \\
\text { vulnerable }\end{array}$ & Primary, relict? & $\mathrm{F}, \mathrm{B}, \mathrm{S}$ & & & Southland \\
\hline Small-eared skink & Oligosoma stenotis & $\begin{array}{l}\text { Naturally } \\
\text { uncommon }\end{array}$ & Primary & $\mathrm{F}, \mathrm{B}, \mathrm{S}$ & & & Stewart Island \\
\hline Scree skink & $\begin{array}{l}\text { Oligosoma } \\
\text { waimatense }\end{array}$ & $\begin{array}{l}\text { Nationally } \\
\text { vulnerable }\end{array}$ & Primary & $\mathrm{F}, \mathrm{B}, \mathrm{S}$ & & & $\begin{array}{l}\text { Marlborough, } \\
\text { Canterbury }\end{array}$ \\
\hline \multicolumn{8}{|l|}{ Fish } \\
\hline Alpine galaxias & $\begin{array}{l}\text { Galaxias } \\
\text { paucispondylus }\end{array}$ & $\begin{array}{l}\text { Naturally } \\
\text { uncommon }\end{array}$ & Facultative & $\mathrm{F}, \mathrm{B}, \mathrm{S}$ & & & $\begin{array}{l}>1200 \mathrm{~m}, \\
\text { Mackenzie Basin }\end{array}$ \\
\hline Dusky galaxias & Galaxias pullus & $\begin{array}{l}\text { Nationally } \\
\text { endangered }\end{array}$ & Facultative & $\mathrm{F}, \mathrm{B}, \mathrm{S}$ & & & $\begin{array}{l}>1050 \mathrm{~m} \text {, Taieri } \\
\text { Catchment }\end{array}$ \\
\hline $\begin{array}{l}\text { Clutha flathead } \\
\text { galaxias }\end{array}$ & $\begin{array}{l}\text { Galaxias } \\
\text { "species D" }\end{array}$ & $\begin{array}{l}\text { Nationally } \\
\text { critical }\end{array}$ & Facultative & $\mathrm{F}, \mathrm{B}, \mathrm{S}$ & & & $\begin{array}{l}>1070 \mathrm{~m} \text {, Clutha } \\
\text { Catchment }\end{array}$ \\
\hline $\begin{array}{l}\text { Canterbury } \\
\text { galaxias }\end{array}$ & Galaxias vulgaris & Declining & Facultative & $\mathrm{F}, \mathrm{B}, \mathrm{S}$ & & & $\begin{array}{l}>1100 \mathrm{~m}, \\
\text { Ashburton } \\
\text { Catchment }\end{array}$ \\
\hline Koaro & $\begin{array}{l}\text { Galaxias } \\
\text { brevipinnis }\end{array}$ & Declining & Facultative & $\mathrm{F}, \mathrm{B}, \mathrm{S}$ & & & $\begin{array}{l}\text { To } 1390 \text { m, } \\
\text { Kahurangi }\end{array}$ \\
\hline $\begin{array}{l}\text { Upland longjaw } \\
\text { galaxias }\end{array}$ & $\begin{array}{l}\text { Galaxias } \\
\text { prognathus }\end{array}$ & $\begin{array}{l}\text { Nationally } \\
\text { vulnerable }\end{array}$ & Facultative & $\mathrm{F}, \mathrm{B}, \mathrm{S}$ & & & $\begin{array}{l}>1200 \mathrm{~m}, \\
\text { Mackenzie Basin }\end{array}$ \\
\hline Gollum galaxias & $\begin{array}{l}\text { Galaxias } \\
\text { gollumoides }\end{array}$ & $\begin{array}{l}\text { Nationally } \\
\text { vulnerable }\end{array}$ & Facultative & $\mathrm{F}, \mathrm{B}, \mathrm{S}$ & & & $\begin{array}{l}1060 \mathrm{~m}, \text { Nevis } \\
\text { Catchment }\end{array}$ \\
\hline Upland bully & $\begin{array}{l}\text { Gobiomorphus } \\
\text { breviceps }\end{array}$ & Not threatened & Facultative & $\mathrm{F}, \mathrm{B}, \mathrm{S}$ & & & $\begin{array}{l}>1200 \mathrm{~m}, \\
\text { Ashburton } \\
\text { Catchment }\end{array}$ \\
\hline
\end{tabular}

1. Source: Goodman et al. 2013; Robertson et al. 2013; Hitchmough et al. 2016.

2. Dependence on alpine zone: Obligate $=$ Restricted to the alpine zone for at least part of its life history; Primary $=$ Lives in a range of lowland, montane and alpine habitats but the alpine zone is an important habitat; Facultative = Can occur incidentally or locally in the alpine zone but is not dependent on it.

3. Use code: $\mathrm{F}=$ Feed, $\mathrm{B}=$ Breed, $\mathrm{S}=$ Shelter.

4. See text of this review for detail. Blank spaces indicate no confirmation of mammalian predation was found.

5. See Basse et al. 1999; Dowding \& Murphy 2001; McLennan \& McCann 2002; Sanders \& Maloney 2002; Baker 2006; Innes et al. 2010; Keye et al. 2011; Reardon et al. 2012; O’Donnell et al. 2015.

use the zone only for breeding, foraging at sea for the rest of the year (Cuthbert \& Davis 2002), and takahē nest in alpine habitat during the spring and forage there until late autumn, when they move down and utilise forest habitats during the winter (Mills et al. 1980). Only rock wrens are truly confined to the alpine zone, except perhaps when dispersing between suitable sites (Weston et al. 2016).

A popular misconception is that kea (Nestor notabilis) use only alpine habitat, perhaps the result of their common description as 'the world's only alpine parrot'. While alpine areas constitute an important component of kea habitat, kea are sequential foraging specialists, commonly found in coastal and montane forests and moving among numerous seasonally available food sources (O’Donnell \& Dilks 1994; Greer et al. 2015). In addition, Jackson (1963) dispelled the myth that kea nest in alpine areas, describing 33 of 36 nests below the timberline in high altitude montane forests, and the remaining three in subalpine scrub. The New Zealand pipit (Anthus novaeseelandiae) specialises in grassland and open habitats, with a breeding range extending from coastal dunes up to high altitude alpine fellfields (Higgins et al. 2006; Beauchamp 2009); consequently, alpine areas are an important habitat for this species. The alpine zone also supports a number of species that exploit high altitude habitats but are not confined to them. These include wetland species that use high altitude fens, flushes, lakes, tarns and streams and shrubland species (e.g. grey duck (Anas superciliosa), black-fronted tern (Chlidonias albostriatus), NZ scaup (Aythya novaeseelandiae), fernbird (Bowdleria punctata), tomtit (Petroica macrocephala), silvereye (Zosterops lateralis); Table 1). Similarly, whio (Hymenolaimus malacorhynchos) frequently feed and sometimes breed in alpine streams (Harding 1990, 1994).

Several threatened species are now restricted to local distributions in the alpine zone (Table 1). Haast tokoeka (Apteryx australis 'Haast') are confined to forests and alpine areas in the Haast Range, South Westland; Hutton's 
shearwaters breed only in the Kaikoura Ranges at elevations between 1200 and 1800 metres; takahē occur naturally only in the Murchison Mountains, Fiordland; and southern New Zealand dotterels (Charadrius o. obscurus) breed only on the Tin Range and Table Hill on Stewart Island (Dowding 1999). Other species use the alpine zone seasonally, and perhaps not every year (e.g. kākā (Nestor meridionalis) when mountain flax (Phormium cookianum) flowers; P. Wilson \& T. Greene, DOC Christchurch, pers. comm.).

It is uncertain how many of these restricted distributions are relicts of wider distributions in the past. There is no evidence that Hutton's shearwaters nested beyond the Kaikoura Ranges (Cuthbert 2001). However, in pre-historic times, takahē were distributed throughout the South Island and were not confined to the alpine zone (Worthy \& Holdaway 2002). Similarly, breeding southern New Zealand dotterels were widespread in the alpine areas of the South Island when Europeans arrived in the country (Stead 1927; Dowding 1999). Fernbirds are widespread in some regions but not others. For example, they are common in alpine tussock and shrublands in the Paparoa Range, north-west Nelson and the central North Island, and occasionally in other alpine areas (Authors, pers. obs.; Robertson et al. 2007), but it is not known if they were distributed more widely in alpine zones in the past. Further, some bird species are now locally extinct in alpine areas; for example, kea have disappeared from the North Island (Tennyson et al. 2014). It has not been confirmed whether rock wrens were once present in the North Island, though a specimen labelled as $X$. gilviventris held at the Natural History Museum at Tring in the United Kingdom is recorded as being collected in the Rimutaka Ranges. If this is an accurately labelled rock wren specimen, then rock wrens have become extinct in alpine areas of the North Island since the 1930s. Kākāpo (Strigops habroptilus) were also found in subalpine scrub and tussocklands in Fiordland and on Stewart Island up until the 1980s (Powlesland et al. 2006).

There is little doubt that the alpine bird fauna was more diverse prior to the arrival of humans in New Zealand (Worthy \& Holdaway 2002), although there is scant information available on the community composition or the relative importance of alpine habitats compared with other zones. It is unlikely that any extinct species were obligate alpine species, although it may have been a primary habitat for several. South Island snipe (Coenocorypha iredali) were thought to be found primarily in tussockland above the timberline (Tennyson \& Martinson 2006), similar to extant Coenocorypha spp., which are common breeders in alpine-like tussocklands and herbfields in subantarctic New Zealand (Miskelly et al. 2006). The long-billed wren (Dendrocansor decurvirostris) was also thought to inhabit high altitude montane forests, subalpine scrub and tussock (Worthy \& Holdaway 2002). A number of moa species (Dinornis, Pachyornis, Megalapteryx spp.), Lyall's wrens (Traversia lyallii), Haast's eagles (Harpogornis moorei), Eyles's harriers (Circus eylesi) and others were probably present in fellfields and high altitude shrublands, at least seasonally (Worthy \& Holdaway 2002).

Some indigenous birds fulfil an important ecological role in the alpine zone as pollinators and seed dispersers. For example, rock wrens consume nectar from mountain flax, thus acting as pollinators, as well as feeding on a range of alpine fruits (Michelsen 1982; O’Donnell et al. 2011). New Zealand falcons (Falco novaeseelandiae) eat fruits of Gaultheria depressa and Leucopogon fraseri (Young \& Bell 2010), New Zealand pipits have been observed feeding on fruits (Young et al. 2012) and whio frequently pass faeces entirely composed of Coprosma spp. (Harding 1990). In addition, birds of prey may act as secondary seed dispersers when they prey on other fruit/seed eaters (Young \& Bell 2010). The relative importance of indigenous birds as pollinators and seed dispersers in the alpine zone is uncertain due to few quantified studies. Compared with invertebrates, alpine birds are likely to play an incidental role as pollinators, but they appear more important as seed dispersers (Primack 1978). Kea are the most important alpine avian frugivore (Young et al.2012), however numerous other alpine frugivores are now extinct (Worthy \& Holdaway 2002). Earlier research indicated that kea were primarily seed destroyers in forests (O’Donnell \& Dilks 1994) and sometimes seed destroyers in the alpine zone (Clarke 1970), but Young et al. (2012) demonstrated through faecal analysis that in two alpine areas, rates of seed predation were extremely low; with seeds of $>20$ plant species passing through the gut and remaining viable. In addition, kea make frequent long distance movements on a scale of tens of kilometres (Clarke 1970), potentially making them effective seed dispersers.

\section{Lizards}

Alpine areas of New Zealand have a diverse lizard fauna, with at least 13 gecko and 17 skink species recorded (Table 1; based on NZ Herpetofauna database). However, populations are generally poorly surveyed and understood. Distributions of most taxa appear highly localised, and like many other reptile taxa in New Zealand, are probably relicts of former, more widespread distributions (Worthy 1987). About one quarter of alpine lizards may be obligate alpine species (seven taxa; Table 1), and the majority of other taxa are widespread at lower altitudes. It has been argued that the black-eyed gecko (Mokopirirakau kahutarae) is New Zealand's only truly alpine lizard, inhabiting cliffs and bluffs between 1250 and 2200 m.a.s.l. in eastern Marlborough and at Mt Arthur in Kahurangi National Park (Whitaker 1984, 1997; Whitaker et al. 1999). However, several newly identified taxa also appear restricted to the alpine zone between 1200 and $1500 \mathrm{~m}$, such as the Mt Arthur and Roy's Peak geckos (Nielsen et al. 2011), and the Barrier and Sinbad skinks (Oligosoma judgei, O. pikitanga) (Bell \& Patterson 2008; Patterson \& Bell 2009). It remains uncertain whether these taxa are true alpine obligates, or if lower altitude populations have been extirpated in the past (Whitaker et al. 1999; Bell \& Patterson 2008; Patterson \& Bell 2009). Several species formerly considered to be alpine specialists have been discovered at low elevation, making us re-evaluate habitat choices and suggesting that the alpine zone provides refugia for formerly widespread species. For example, the range of the Takitimu gecko (M. cryptozoicus) was recently extended to include low altitude forest in the Waitutu area (Bell \& Patterson 2008).

Lizards may play an important role as pollinators, being more local dispersal agents for alpine plants, though little is known in general of their effectiveness (quantity and quality) for most New Zealand flora (Whitaker 1987; Young \& Kelly 2014; Wotton et al. 2016). Several alpine lizard taxa are known to visit flowers to feed on nectar and also remove and ingest fruits, excreting viable seed of several montane grassland species (Whitaker 1987; Lawrence 1997). A recent study of alpine fruit removal rates in the central Southern Alps showed the contribution of lizards to be unexpectedly high; constituting on average $50 \%$ of total fruit removal (Young \& Kelly 2014). 


\section{Invertebrates}

The New Zealand alpine zone supports a rich and extensive array of endemic invertebrate groups; some of the most notable include wētā and short-horned grasshoppers (Orthoptera), cockroaches (Blattodea), cicadas (Homoptera), weevils (Coleoptera), butterflies and moths (Lepidoptera), giant wingless stoneflies (Plecoptera), spiders (Araneae) and giant carnivorous snails (Mollusca). Many of these taxa possess specialised adaptations to survive the extreme alpine conditions such as dark colouration, flightlessness and freeze tolerance (Buckley \& Simon 2007; McCulloch et al. 2009; Wharton 2011). Patterns such as low levels of endemism within the volcanic mountainous areas of the North Island, and high levels of endemism in the alpine areas of north-west Nelson and west Otago have been identified, as well as hotspots of local endemism on individual mountain ranges, though detailed information on alpine fauna distributions across New Zealand remains lacking (Goldberg et al. 2008; Buckley et al. 2015).

Amongst wētā, perhaps the most charismatic alpine dwellers are those from the genus Deinacrida (giant wētā). Of the eleven giant wētā species, six are classified as alpine, three of which are obligate alpine inhabitants and restricted to localised regions of the South Island mountains (MorganRichards \& Gibbs 2001). Deinacrida talpa is known only from the central Paparoa Range, on the West Coast of the South Island (Gibbs 1999), and D. parva survives as a relict in the Kaikoura Ranges of the northern South Island (Gibbs 1998). Each species of giant wētā is specialised to use different alpine microhabitats, ranging from rocky crevices and bluffs, to scree slopes and self-excavated underground burrows (MorganRichards \& Gibbs 2001). Only two species, D. connectens and $D$. pluvialis, are not classified as at risk, attributed to their relative wide ranges throughout the Southern Alps (Trewick et al. 2012). Several species of Rhaphidophoridae (cave wētā), such as the iconic 'Mount Cook Flea' Pharmacus montanus, are also obligate alpine dwellers, found only in some of the highest alpine-nival zones of the Southern Alps (Richards 1972). Some wētā species, such as D. connectens and ground wētā Hemiandrus maculifrons, are thought to be seed dispersers of alpine plants (Burns 2006; Larsen \& Burns 2012). However, the overall contribution of wētā to effective alpine seed dispersal is thought to be low (Morgan-Richards et al. 2008; Young \& Kelly 2014).

Solitary bees (Hymenoptera), native flies (Diptera) and moths comprise the majority of insect pollinators within the New Zealand alpine zone (Primack 1978, 1983; Bischoff 2008; Bischoff et al. 2013). Unlike in the alpine regions of Europe and North America, native social bees (Hymenoptera) are absent and butterflies are scarce, with only five described obligate alpine dwellers; the endemic black mountain ringlet (Percnodaimon merula), Butler's ringlet (Erebiola butleri), and alpine boulder butterflies Lycaena spp. (Gibbs 1980; Newstrom \& Robertson 2005; Patrick \& Patrick 2012). Most of New Zealand's short-horned grasshoppers (Orthoptera: Acrididae) are confined to alpine or subalpine habitats and hence as a group, they are generally referred to as alpine grasshoppers, despite some species being only primary or facultative in their dependence on the alpine zone (Bigelow 1967; Trewick 2008). The Homer grasshopper (Sigaus homerensis) is only known from the Earl Mountains of Fiordland (Morris 2003) and is ranked as nationally critical under New Zealand threat ranking criteria (Trewick et al. 2012). Only one species, S. piliferus, has been recorded from alpine areas of the North Island (Bigelow 1967). As a group, the short-horned grasshoppers represent a significant guild of herbivores in the New Zealand alpine zone (Batcheler 1967; White 1975).

Within the New Zealand cicada genus Maoricicada, there are 14 described species, nine of which can be considered either alpine or subalpine (Dugdale \& Fleming 1978; Buckley $\&$ Simon 2007). The genus has speciated extensively in the South Island mountains and several species are severely range restricted. For example, $M$. otagoensis maceweni is known only from the Takitimu Range in Southland (Dugdale \& Fleming 1978). These cicadas utilise a diversity of habitat types, ranging from subalpine scrub and screes, to boulder and herbfields adjacent to the permanent snow line (Buckley \& Simon 2007). Similarly, within the cicada genus Kikihia, many species are found in specific habitats (e.g. K. horologium are mostly found on subalpine shrubs). It is likely that new species were formed by adaptation to new alpine habitat types during the rapid uplift of the Southern Alps 3-5 Ma (Arensburger et al. 2004). Similar patterns with hotspots of local endemics are found among the alpine stoneflies (McLellan 1977; McCulloch et al. 2010). The Lyperobius or 'speargrass' weevils are predominantly found in higher montane, subalpine and alpine grasslands, or herbfields and rocky habitats in the South Island (Craw 1999). These large flightless weevils feed exclusively on herbaceous plants from the family Apiaceae in two genera - Aciphylla and Anisotome (Craw 1999). At least one obligate alpine species, L. carinatus, is currently listed as threatened, attributed to being uncommon throughout its range (Leschen et al. 2012). Carnivorous land snails belonging to the genus Powelliphanta are also found throughout the alpine areas of New Zealand, with the greatest diversity of species in the mountains of north-west Nelson (Walker 2003). At least ten Powelliphanta species are obligate users of subalpine scrub and alpine tussock grasslands, some spending up to 5 months of the year under snow and able to withstand below-freezing conditions (Walker 2003).

\section{Freshwater fish}

Overall, there are few records of freshwater fish in alpine areas. With $>34000$ survey records in the NZ Freshwater Fish Database (NZFFD), only 203 were in alpine areas above 1000 m.a.s.l., and fish were recorded on only 63 of these 203 sites (NZFFD, August 2015). Eight of the 56 New Zealand indigenous freshwater fish taxa (Goodman et al. 2013) have been recorded in the alpine zone (Table 1; NZFFD), but none are obligate alpine species. Koaro (Galaxias brevipennis) have been recorded to 1390 m.a.s.l. in Kahurangi National Park. Two taxa were recorded as common or abundant at a few sites (upland longjaw galaxias $G$. prognathus and alpine galaxias $G$. paucispondylus), but most taxa were recorded in only one or few reports.

\section{Bats}

New Zealand bats are essentially forest dwelling species (O'Donnell et al. 1999; O'Donnell 2001). There have been reports of long-tailed bats (Chalinolobus tuberculatus) foraging up to the timberline, but not above it (Dwyer 1962; Daniel \& Williams 1984). 


\section{Distribution and ecology of alpine mammalian predators}

Studies documenting mammalian predator ecology above the timberline are sparse and distribution records are not formally collated anywhere. Trap catch data collated from several alpine sites, combined with anecdotal records from managed alpine sites, show that almost the full suite of predators known to be present below the timberline are also present in the alpine zone (Fig. 2). These predator control programmes include a range of trap-box entrances and trap types, which may have been optimised for different predators; consequently, the number of captures may not reflect actual composition (Fig. 2). Alpine tracking tunnels (Gillies \& Williams 2013) have mainly recorded stoats and house mice (Mus musculus) (DOC, unpubl. data). However, in situations where mustelid or rodent detectability and/or density is low, such as has been suggested for alpine zones in general, tracking tunnels are not always sensitive enough to confirm presence/absence (Choquenot et al. 2001; Gillies \& Williams 2013; Pickerell et al. 2014). The lack of alpine records of feral ferrets (Mustela furo) and the apparent patchiness of other predators, is not evidence for absence of these taxa, largely because of the paucity of studies at high altitude. Although most mammalian predators are present in the alpine zone, there is little information available on actual or relative abundance compared with other habitat types.

\section{Mustelids}

Stoats (Mustela erminea) are widespread throughout New Zealand and are able to live in any habitat where they can find prey (King \& Murphy 2005). Both trapping and tracking tunnel studies indicate stoats are common in alpine areas (Fig. 2; Smith et al. 2005; Wilson et al. 2006), which is not surprising given that they are cold-adapted animals (King \& Powell 2007) with the majority of their global range lying north of latitude $45^{\circ}$ and associated with boreal and subalpine biomes (King \& Powell 2007; Frey \& Calkins 2014).
Population densities of stoats are considered to be lower and more stable in non-beech-forest habitats (King \& Murphy 2005), though within an alpine Hutton's shearwater colony in the Kaikoura Ranges stoat density was the highest recorded in any habitat (c. 17 stoats per $\mathrm{km}^{2}$ ) during the shearwater nesting season, when prey were superabundant (Cuthbert \& Sommer 2002). Limited trapping data (Fig. 2) indicate that stoat capture rates vary markedly from year to year in South Island areas adjacent to beech sites, compared with Mt Taranaki where adjacent forest is podocarp-hardwood; this difference may be related to mast seedfall events within the alpine zone or in adjacent beech forests.

Standard tracking tunnel indices have been used to investigate differences in stoat abundance between alpine grassland and beech forest in the Murchison Mountains and Borland Valley of Fiordland (Smith \& Jamieson 2005; Wilson et al. 2006). In the Murchison Mountains in a summer following two consecutive heavy beech seedfall events and a weak Chionochloa seed mast, stoat densities were significantly higher at beech forest sites (Smith \& Jamieson 2005), but in the Borland Valley where no heavy beech or Chionochloa tussock seedfall events had occurred, no significant difference in stoat tracking between alpine and beech forest habitats was detected (Wilson et al. 2006). In the Borland Valley, stoat density (c. one stoat per $\mathrm{km}^{2}$ ) and body weights were similar between alpine and forest habitats (Smith et al. 2008), and stoats preferentially selected alpine grassland habitat over adjacent lower elevation beech forest within their home ranges (Smith et al. 2007).

In the Murchison Mountains, mice were the most common prey of stoats, following a heavy beech and tussock seedfall event (Smith et al. 2005). While the limited diet studies to date imply geographical variation in the contribution of alpine invertebrates to stoat diet, there is strong evidence that wētā are the most common invertebrate prey of alpine stoats (Lavers \& Mills 1978; Cuthbert et al. 2000; Smith et al. 2005, 2008), particularly during years when no heavy seeding of beech or Chionochloa occurs and rodents are scarce (Smith et al.

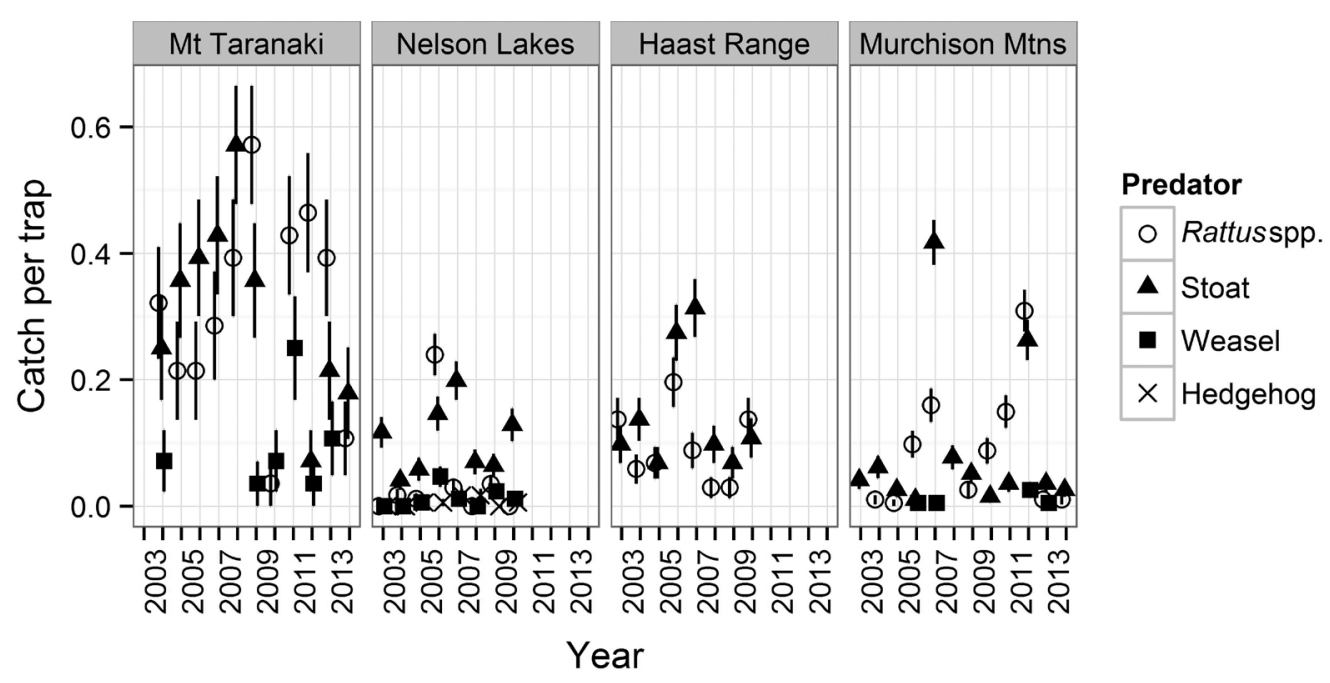

Figure 2. Trapping rates (uncorrected trap catch \pm SE) of mammalian alpine predators from Mt Taranaki $(1290-1540 \mathrm{~m} . \mathrm{a} . \mathrm{s} .1 ; \mathrm{n}=191$ captures; 28 double DOC180 traps; 2004-2014), Nelson Lakes National Park (1320-1880 m.a.s.1; n = 224 captures; 171 single DOC200 traps; 2003-2010), Haast Range, South Westland (980-1470 m.a.s.1; $n=195$ captures; 102 double DOC200 traps; 2003-2010) and Murchison Mountains, Fiordland (1000-1390 m.a.s.1; n= 193 captures; 194 double DOC150 traps; 2003-2014). (See Poutu \& Warburton 2005, for further detail on DOC series trap design). 
2005, 2008). Supplementary feeding experiments with stoats in alpine habitat also indicate that stoats may alter the rate at which they prey upon wētā in alpine grasslands, when other food sources are abundant (Smith et al. 2011).

Weasels (Mustela nivalis) are less common and more patchily distributed across New Zealand than stoats, and prefer thick ground cover to more open country (King 2005). However, weasels are caught regularly in alpine trapping programmes (Fig. 2). Dietary studies of weasels in alpine habitat have not been undertaken, though the few data available from lowland habitats indicate that mice comprise much of weasel diet and that larger prey items such as rats and lagomorphs are consumed less frequently (King et al. 1996; Murphy et al. 1998). When supplied with abundant food, weasels are capable of producing up to three litters per season and can breed in the year of their birth; by contrast, stoats do not produce their first litter until they are 12 months old and produce only a single litter per season (King 2005). Therefore, weasels are more closely adapted than stoats to exploit irruptions in small mammals, and consequently their New Zealand distribution and rapid fluctuations in abundance are closely correlated with the distribution and abundance of mice (King 2005). Weasels cannot be reliably distinguished from stoats using tracking tunnel footprints (C. Gillies, DOC Hamilton, pers. comm.), so it is uncertain how extensively they occupy alpine environments.

\section{Rodents}

House mice are found throughout the New Zealand mainland, from the coast to high altitudes (Ruscoe \& Murphy 2005). They generally reach higher population densities in areas with dense ground cover, and habitat choice is a trade-off between access to food and safety from predation (Ylönen et al. 2002; Ruscoe \& Murphy 2005). We are aware of only one published assessment of mouse diet in the alpine zone (alpine grasslands, Borland Valley, Fiordland) (Wilson et al. 2006; Wilson \& Lee 2010). In this habitat, mouse diet appeared to be dominated by invertebrates during non-tussock-mast years and by Chionochloa tussock seed during a mast seedfall year, when mouse density increased from $4 \mathrm{ha}^{-1}$ to $39 \mathrm{ha}^{-1}$ (Wilson \& Lee 2010). Mouse populations also irrupt in beech and podocarp-hardwood forest following moderate to high seedfall because this abundant food supply facilitates winter breeding (King 1983; Murphy 1992; Fitzgerald et al. 1996; O’Donnell \& Phillipson 1996; Choquenot \& Ruscoe 2000; Ruscoe et al. 2004). The extent to which alpine mice respond to tussock mast seeding, compared with their response to seedfall events in adjacent forests, has been documented only once in New Zealand (Wilson \& Lee 2010). There is uncertainty also as to whether there is spillover of mice into alpine habitat from adjacent forest in high beech seedfall years, or indeed, vice versa during Chionochloa mast or other pulsed seeding events in alpine vegetation. In the Borland Valley, densities of mice were consistently higher in alpine habitat compared with adjacent montane beech forest in years prior to tussock seeding, but mice were not monitored in adjacent forest during or after the Chionochloa mast seeding year (Wilson \& Lee 2010).

We found confirmed reports of all three rat species (ship rats (Rattus rattus), Norway rats ( $R$. norvegicus) and Pacific rats (kiore, $R$. exulans)), in alpine areas (Table 2). However, misidentification and failure to identify rats to species during alpine trapping programmes impedes knowledge about distribution (Ruscoe 2004). Consequently, in this review, we refer to 'Rattus spp.' where the species of rat is unknown. All three rat species are omnivorous generalists, each consuming a wide range of invertebrates and plant parts including seeds and fruits, and, less often, lizards and birds (Atkinson \& Towns 2005; Innes 2005a, b). As with mice, rat populations irrupt in beech and podocarp-hardwood forest due to increased food supply following moderate to high seedfall (King \& Moller 1997; Harper 2005a).

Table 2. Known records of mammalian predators from selected New Zealand alpine sites

\begin{tabular}{|c|c|c|c|c|c|c|c|c|c|c|c|c|}
\hline & Stoat & Weasel & $\begin{array}{c}\text { Feral } \\
\text { cat }\end{array}$ & $\begin{array}{l}\text { Hedge } \\
\text {-hog }\end{array}$ & $\begin{array}{l}\text { Pacific } \\
\text { rat }\end{array}$ & $\begin{array}{l}\text { Norway } \\
\text { rat }\end{array}$ & $\begin{array}{l}\text { Ship } \\
\text { rat }\end{array}$ & $\begin{array}{l}\text { House } \\
\text { mouse }\end{array}$ & $\begin{array}{c}\text { Feral } \\
\text { pig }\end{array}$ & $\begin{array}{l}\text { Deer } \\
\text { spp. }\end{array}$ & $\begin{array}{l}\text { Brushtail } \\
\text { possum }\end{array}$ & Source \\
\hline Mount Taranaki & Yes & Yes & - & - & - & - & Yes & - & - & - & - & $\begin{array}{l}\text { Monitoring \& trapping data, DOC } \\
\text { Taranaki }\end{array}$ \\
\hline Kahurangi & Yes & Yes & - & - & - & - & Yes & Yes & Yes & - & Yes & $\begin{array}{l}\text { Authors unpubl. data; Friends of } \\
\text { Flora; Friends of the Cobb; J. } \\
\text { Kemp pers. comm. }\end{array}$ \\
\hline Kaikoura Ranges & Yes & - & Yes & - & - & - & - & Yes & Yes & - & - & $\begin{array}{l}\text { G. Taylor pers. comm.; Cuthbert \& } \\
\text { Davis 2002; Cuthbert } 2002\end{array}$ \\
\hline Nelson Lakes & Yes & Yes & - & Yes & - & - & Yes & Yes & - & - & - & $\begin{array}{l}\text { J. Mace pers. comm.; Monitoring } \\
\text { \& trapping data, DOC Nelson Lakes }\end{array}$ \\
\hline Haast Range & Yes & - & - & - & - & - & Yes & Yes & - & Yes & Yes & $\begin{array}{l}\text { Authors unpubl. data; Monitoring } \\
\text { \& trapping data, DOC Haast }\end{array}$ \\
\hline Arthurs Pass & Yes & - & Yes & - & - & - & - & Yes & Yes & Yes & Yes & Authors unpubl. trail camera data \\
\hline $\begin{array}{l}\text { Aoraki/Mount } \\
\text { Cook }\end{array}$ & Yes & - & Yes & - & - & - & - & Yes & - & - & Yes & $\begin{array}{l}\text { A. Warren pers. comm.; P. } \\
\text { Hondelink pers. comm. }\end{array}$ \\
\hline $\begin{array}{l}\text { Homer-Gertrude } \\
\text { Cirque }\end{array}$ & Yes & - & - & - & - & - & Yes & Yes & - & - & Yes & $\begin{array}{l}\text { Authors unpubl. data; NZAC } \\
\text { trapping data }\end{array}$ \\
\hline $\begin{array}{l}\text { Murchison } \\
\text { Mountains }\end{array}$ & Yes & Yes & - & - & Yes & - & Yes & Yes & - & Yes & - & $\begin{array}{l}\text { Monitoring \& trapping data, DOC } \\
\text { Te Anau; J. Christie pers. comm. }\end{array}$ \\
\hline Stewart Island & - & - & Yes & - & - & Yes & - & - & - & Yes & - & $\begin{array}{l}\text { Monitoring \& trapping data, DOC } \\
\text { Rakiura }\end{array}$ \\
\hline
\end{tabular}


Norway rats were widespread on the mainland in the nineteenth century, but now tend to survive best in wetland habitats and are generally absent from high elevations (Innes 2005a). On Stewart Island, they are still found in alpine areas (K. Richardson, DOC Stewart Island, pers. comm.) and at large distances from water (Hickson et al. 1986; Harper 2005b).

Ship rats are generally found from coast to timberline (Innes 2005b), though trap catch data collected across an altitudinal gradient shows a negative effect of increasing elevation (Studholme 2000; Christie et al.2017). Although ship rats were previously reported to be absent from alpine tussock (Innes 2005b), recent trap catch data (Fig. 2) reveals that Rattus spp. are frequently present above the timberline, including within tussock grassland habitat, albeit in low numbers. Given that on the mainland kiore are now apparently confined to parts of Fiordland, Southland and South Westland, and Norway rats are generally absent from higher elevations, it is most likely that the Rattus spp. captured from the northern alpine sites (Taranaki and Nelson Lakes) were ship rats (Fig. 2). Like stoats, numbers of Rattus spp. trapped above the timberline fluctuate among years and within seasons (Fig. 2). Predicted rising temperatures associated with climate change will further facilitate the invasion of ship rats into higher altitude areas, though the interplay between temperature and other drivers of rat abundance such as invertebrate activity and mast seeding of grasses, herbs or shrubs remains unclear (Studholme 2000; Christie et al. 2017).

\section{Possums}

Brushtail possums are present throughout most of New Zealand (Clout \& Ericksen 2000), but little information is available on their distribution and ecology in alpine areas. In the North Island, they are absent only above $2400 \mathrm{~m}$ on the upper slopes of Mts Taranaki and Ruapehu, whereas in the South Island, they are absent above $1800 \mathrm{~m}$ (Cowan 2005). It seems likely that the spread of possums into alpine areas, particularly in Fiordland and South Westland, has been slowed by the topography and harsh climatic conditions. Possum habitat studies in the central Southern Alps indicate that possums are common, albeit at low densities, in sub-alpine shrubland and occur less commonly within alpine grassland habitats (Coleman et al. 1980; Hickling \& Forsyth 2000). Shrubland is likely preferred over alpine grasslands because the heterogeneity of shrubland habitat provides more suitable den sites for shelter and alpine grasses are rarely eaten by possums (Hickling \& Forsyth 2000; Parkes \& Forsyth 2008; Glen et al. 2012).

In the north east of the South Island, possum capture rates declined with increasing altitude, from 600 to $>1600 \mathrm{~m}$, and also towards wetter western areas (Glen et al. 2012). Home ranges in high-altitude habitat were larger compared with those typical of forested areas, which was again attributed to more sparsely distributed resources such as food and den sites in open, high-altitude habitat (Glen et al. 2012). In spite of these perceived differences in habitat quality, mean body weights of adult possums in the central Southern Alps are the largest recorded for a New Zealand population, suggesting it is den sites, as opposed to food, that is limiting (Hickling \& Forsyth 2000). Survival rates in high-altitude habitat were also similar to those elsewhere in New Zealand (Glen et al. 2012).

Although possums are primarily folivores, they eatflowers, fruit, fungi and small quantities of invertebrates in all habitats (Nugent et al. 2000) and occasionally birds and eggs (Brown et al. 1993). Limited evidence suggests that possums select non-foliar foods for their high nutritional value, and that possum carrying capacity may be linked to the availability of these foods in different habitats (Nugent et al. 2000). How much possums prey on alpine fauna is unknown.

\section{Hedgehogs}

European hedgehogs (Erinaceus europaeus occidentalis) are abundant throughout lowland New Zealand, particularly in coastal areas (Brockie 1975; Jones \& Sanders 2005). They are thought to be limited by climate at higher elevations and their abundance generally decreases with altitude; however, they have been recorded as high as 2000 m.a.s.l. in the mountains of the South Island (Brockie 1975). Trap catch data indicate they can be trapped regularly in certain alpine areas (Fig. 2). Hedgehog habitat is largely associated with the availability of invertebrate prey and dry nest sites; warmer, drier areas with fewer and milder frosts tend to be favoured (Jones \& Sanders 2005). Dietary studies from a range of habitats, but not alpine areas, indicate that invertebrates comprise much of hedgehog diet, though vertebrates such as lizards, birds (particularly eggs) and carrion are also eaten where available (Berry 1999; Jones \& Sanders 2005; Jones et al. 2005). Thus, where hedgehogs dwell above the timberline they are likely to pose some level of threat to alpine fauna.

\section{Cats}

Feral cats (Felis catus) are distributed throughout New Zealand and can live in most habitats, including sand dunes, pasture, tussock, scrub, exotic plantations and native forest (Gillies \& Fitzgerald 2005). They have been recorded from sea-level to $3000 \mathrm{~m}$ (Collins \& Charleston 1979). In lower altitude tussock grassland and braided riverbed habitats, lagomorphs (mainly rabbits (Oryctolagus cuniculus)) are cats' most frequent prey; with birds, rodents, invertebrates and lizards also consumed depending on their local availability (Murphy et al. 2004; Gillies \& Fitzgerald 2005). On Stewart Island, where lagomorphs are absent, ship rats are the primary prey of cats, regardless of their abundance, and birds are their main alternative prey (Harper 2005b). However, there appear to be no data on cat density or prey consumed in alpine areas.

Feral cat home ranges in high country braided river valleys include steep sided slopes adjacent to riverbeds, and several radio tracked individuals have been recorded in the alpine zone (1100-1700 m.a.s.1.) in winter, including in tussock dominated alpine valleys and amongst scree (Recio et al.2010). They may range in the alpine zone in search of juvenile hares during the peak of the hare breeding season (Recio et al. 2014).

\section{Pigs}

Feral pigs (Sus scrofa) occupy approximately a third of New Zealand and are still expanding in range (Fraser et al. 2000). Preferred habitats are native and exotic forests, regenerating farmland, river flats and tussock grasslands with patches of scrub for shelter, which therefore limits pigs' use of alpine areas (McIlroy 2005). They are opportunistic omnivores, and feed on a range of plants above the timberline such as the roots of Aciphylla spp., grasses, and the lower part of Chionochloa tillers, as well as digging and churning surface substrates. Animal material constitutes an important component of their diet, particularly when breeding, and includes invertebrates, lizards, ground-nesting birds and their eggs, mice, Rattus spp., young rabbits, and carrion (Cuthbert 2001; McIlroy 2005), so alpine fauna are likely to be under threat where pigs are present. 


\begin{abstract}
Deer
Deer are adaptable herbivores that both browse and graze, but white-tailed deer (Odocoileus virginianus) have also been recorded preying on the eggs of southern New Zealand dotterels, in their alpine breeding grounds on Stewart Island (K. Richardson, DOC Stewart Island, pers. comm.). Although other deer species commonly use alpine habitat, there appear to be no other records of them preying on fauna. However, it has been shown that deer impact indirectly on takahe in the Murchison Mountains of Fiordland, by competing for Chionochloa tussock as food (Mills \& Mark 1977; Parkes et al. 1978; Lavers et al. 1983).
\end{abstract}

\section{Evidence for the impacts of mammalian predators}

\section{Birds}

Direct evidence for impacts of introduced mammalian predators on avifauna in the alpine zone is limited and often anecdotal, and is largely derived from studies of threatened species that have been a priority for research. Mammalian predators have been identified as nest predators of seven bird species in alpine habitats (Table 1). For the remaining 16 characteristic alpine bird species, there have been no studies of nesting that we know of in the alpine zone, though mammalian predation has been recorded as a threat in other ecosystems (Table 1).

Mice and stoats have been identified as frequent predators on rock wren eggs, nestlings, and adults (Authors, unpubl. data; Michelsen-Heath 1989; Willans \& Weston 2005; Willans 2007). In the McKenzie Burn area of the Murchison Mountains, Fiordland, Michelsen-Heath (1989) found that eight (24\%) of 33 nests failed because of predators, five being preyed on by stoats and three by mice. Similarly, in the Murchison Mountains, two $(17 \%)$ of 12 nests monitored in the Mystery Burn and two (13\%) of 16 nests in the McKenzie Burn failed due to predation(Willans \& Weston 2005; Willans 2007). Where the predators could be identified, stoats preyed on two nests and mice on one nest. However, while it was concluded that predation was having some impact on rock wren populations, these studies were carried out simultaneously with low intensity predator trapping programmes, either to identify the presence of mammalian predators (Michelsen-Heath 1989) or to protect takahē (Willans 2007). The biases caused by the stoat trapping potentially mask the true impact of these predators on rock wrens because an unknown number of predators may have been killed before they could prey upon rock wrens.

More recently, using infrared video monitoring, stoats have been identified as important predators of adult rock wrens at nests (2011-2015; Authors, unpubl. data). In three untrapped areas of Fiordland and South Westland, 60-80\% of nests were preyed upon, including many on bluff systems, and all predation events captured on camera were by stoats (Authors, unpubl. data). Stoats frequently preyed upon cliffnests, and in one case a stoat jumped across a metre-wide gap to reach a nest. There is only one confirmed record of a weasel killing rock wrens; a fixed trail camera showed an individual weasel killing nestlings in Kahurangi National Park in 2015 (T. Rawlence, DOC Nelson, unpubl. data). Likewise, a Rattus spp. was recorded killing rock wren nestlings, also in Kahurangi National Park (T. Rawlence, unpubl. data). However, Reischek (1884) mentioned heavy predation by Norway rats during the nineteenth century when rat plagues were common in the Southern Alps.
Stoats are known to prey upon takahē eggs, chicks, and adults in their natural range in the Murchison Mountains, Fiordland (Reid 1967; Lavers \& Mills 1978; Crouchley 1994; Maxwell \& Christie 2005), although it has also been reported that in at least one instance an adult takahe has successfully fended off and actually killed a stoat (Lavers \& Mills 1978). Predation on eggs appears to be low (3-6\% of fertile eggs; Maxwell \& Christie 2005). Predator impacts can also be inferred from benefits of predator control programmes in takahē habitat in the Murchison Mountains. Annual adult takahē survival increased significantly from $78 \%$ to $85 \%$ in the presence of low density stoat trapping, but was still low relative to the survival rates of translocated takahē populations on predatorfree offshore islands (Hegg et al. 2012). Further, numbers of takahē in Fiordland almost halved (from 168 known individuals to 93) as a consequence of a stoat plague during the winter of 2007 (Hegg et al. 2012). During the winter, takahē are also at risk of predation from stoats inhabiting beech forest at lower altitudes (Smith \& Jamieson 2005) because they move into these forests and grub for the roots of Hypolepis millefolium when access to alpine tussock food resources becomes limited by snowfall (Maxwell 2001).

While there have been no specific studies of predation on whio in alpine habitats, video monitoring of nests identified stoats as the primary nest predator in Fiordland valley ecosystems (Whitehead et al. 2008). Further, low intensity stoat control year-round (10 traps per linear km) significantly reduced stoat abundance in trapped whio habitat compared with untrapped habitat. During the same period, whio nesting success and productivity increased significantly within trapped areas (Whitehead et al. 2008). In central North Island rivers, population viability modelling indicates that cessation of predator trapping would rapidly lead to local extirpation of whio (Simpkins et al. 2015).

Stoats, feral cats and feral pigs prey on Hutton's shearwater in the Kaikoura Ranges (Cuthbert 2002; Cuthbert \& Davis 2002). Stoats were the major cause of shearwater mortality, with evidence of stoat predation found on $58 \%$ of carcasses $(30$ of 52 ); feral cats were likely responsible for $14 \%$ of mortality (7 of 52) (Cuthbert 2001). Overall, stoats were estimated as killing $0.25 \%$ of breeding adults and $12 \%$ of chicks produced annually, resulting in a predicted $0.86 \%$ reduction in population growth per annum (Cuthbert \& Davis 2002). However, because most predation was targeted at chicks, stoat control may not be warranted to protect this species, especially given that natural variation in breeding success due to environmental factors is greater than the effects of predation (Cuthbert 2002). In general, long-lived seabirds like Hutton's shearwaters are much more sensitive to the loss of adults than to the loss of chicks or eggs (Cuthbert 2001). Further, the presence of feral pigs within six extinct colonies of Hutton's shearwaters and at the boundaries of the two extant colonies strongly suggests that pigs were responsible for the historic contraction in breeding range (Cuthbert 2002).

Predation is recognised as the main threat to the southern New Zealand dotterel(Dowding \& Murphy 1993), resulting in the implementation of annual predator control in the dotterels' alpine breeding grounds on Stewart Island (Dowding 1995). However, there are few direct observations of predation to support this assertion (Hope 2014; M. Dobbins, pers. comm.). Feral cats are believed to be the primary predator of these dotterels, responsible for the decline of the population from an estimated 350 individuals in 1955 to 62 individuals in 1992 (Dowding \& Murphy 1993). Subsequent predator control 
may have enabled the slow recovery of the population since the early 1990s (Dowding \& Murphy 1993; Dowding 1999; Hope 2014). Rattus spp. are also thought to have some impact (Dowding 1999) and there is a recent trail camera record of a Norway rat preying on southern New Zealand dotterel eggs (K Richardson, DOC Stewart Island, pers. comm.). Whitetail deer and swamp harrier (C. approximans) have also been recorded taking eggs. Predation on adult dotterels has reduced their life expectancy to approximately 5 years and there is now a female biased sex ratio of 2:1, largely because males are more susceptible to predation as they undertake most of the nocturnal incubation (Dowding 1997 cited in Hope 2014).

Three species of kiwi inhabit alpine areas (Table 1). However, there is little direct evidence of predation on alpine kiwi, largely because studies are few and are predominantly conducted in the lower altitude regions of their range (Keye et al. 2011). Thus, evidence for predation is inferred from these lower altitude studies. Great spotted kiwis have disappeared from lowland sites, probably because of habitat loss and predation. The main agent of decline appears to be predation on chicks and juveniles by stoats (McLennan \& McCann 2002). Stoats are also the main predator of young Fiordland tokoeka, with $24 \%$ of 34 predation events recorded in the Murchison Mountains between 2003 and 2009 occurring above the timberline (Tansell 2009; Edmonds 2015). During this same period, Fiordland tokoeka chick survival was significantly greater in trapped areas of the Murchison Mountains (37\%) than in non-trapped areas (17\%) (Tansell 2009). Modelling of this population indicates a slow decline $(-1.3 \%$ per annum $)$ in the absence of trapping, whereas trapping results in a stable or very slightly increasing population size (1.1\% per annum) (Edmonds 2015). Stoats are also a major predator of the closely related northern brown kiwi (Apteryx mantelli) (Basse et al. 1999). In lowland forests, ferrets and dogs were the main predators of adult brown kiwi and possums and mustelids were the main egg predators, while stoats $(77 \%$ of confirmed predations) and cats were largely responsible for the deaths of young kiwi (McLennan et al. 1996). Haast tokoeka frequently nest above the timberline along the Haast Range in South Westland, and in the few instances where causes of mortality have been confirmed, stoats have been identified preying upon chicks (Gardner 2010).

For kea, predation in adjacent high altitude forests appears to be a significant threat. Although Jackson $(1963,1969)$ found no evidence of predators preying on adult kea or their nests, Elliott and Kemp (2004) found that predators, mainly stoats and possums, had reduced kea populations in the St Arnaud Range in Nelson Lakes National Park, and increased the likelihood of local extinction. In 2010, remote cameras recorded both possums and stoats attacking and killing kea at their nests in South Westland (B. Barrett, pers. comm.).

\section{Lizards}

About $75 \%$ of alpine lizards are threatened or at risk (Table 1; Hitchmough et al. 2016) but as with other alpine species groups, there are few data on impacts of predators on alpine lizards. There is a perception that high altitude lizard sites are rarely visited by mammalian predators (Patterson \& Bell 2009). However, stoats, possums and mice are present on the sheer rock walls $>1100$ m.a.s.l. occupied by Sinbad and cryptic skinks (O. inconspicuum) and Cascade geckos (Mokopirirakau 'Cascades') in Sinbad Gully, Fiordland (Bell \& Patterson 2008; J. Reardon, DOC TeAnau, pers. comm.). Almost all impacts of predators on alpine lizards are inferred from studies at lower altitude, where the impacts of a wide range of mammalian predators have been implicated in declines of several species (Towns \& Daugherty 1994; Tocher 2009; Jones et al. 2013). However, during a recent dietary analysis of stoats in alpine habitat on the Haast Range in South Westland, a Cascade gecko was recovered from the gut of a freshly-trapped stoat (Authors, unpubl. data).

Most evidence for predator impacts on population viability of lizards comes from studies where their numbers increased following predator control. For example, in mid-altitude populations of endangered grand (Oligosoma grande) and Otago skinks (O. otagense), the greatest increase in abundance occurred at the centre of a predator trapping treatment area and inside a mammal-proof fence (Reardon et al. 2012). Similarly, survival in a coastal population of McCann's (Oligosoma maccanni) skinks also increased in areas enclosed by predatorproof fences (Lettink et al. 2010).

\section{Invertebrates}

Evidence for predation by introduced mammalian predators on alpine invertebrates is derived mainly from dietary studies. Lavers and Mills (1978) found that in montane to alpine areas of the Murchison Mountains, ground wētā (Hemiandrus spp., particularly $H$. focalis) were common in the scats of stoats (55\% of samples). At the same sites, Smith et al. (2005) confirmed that ground wētā were an important dietary component, comprising up to $59 \%$ of stoat stomachs. Ground wētā (predominantly $H$. maculifrons) were also identified as the most common prey item of stoats in alpine grasslands in the Borland Valley (Smith et al. 2008). Gibbs (1998) suggested that large alpine Deinacrida wêtā were highly vulnerable to predation due to their ground-dwelling life style, but were not threatened because their habitats are above the elevational limit of rat invasion. However, in an alpine breeding colony of Hutton's shearwaters, D. parva were common in stoat diets, particularly once the majority of young shearwaters had fledged and departed the colony (Cuthbert et al. 2000). Other invertebrate prey items consumed by stoats include Orthopterans (grasshoppers) and representatives of the orders Coleoptera, Diptera, Hymenoptera, Lepidoptera, Araneae and Gastropoda (Smith et al. 2005, 2008).

Greater numbers of invertebrates are consumed by individual mice when Chionochloa tussock species are not mast-seeding (Wilson \& Lee 2010). Invertebrate groups eaten by alpine mice include ground wētā ( $36 \%$ of stomachs), spiders $(34 \%)$, caterpillars (Lepidoptera) $(15 \%)$ and grasshoppers (13\%) (Wilson \& Lee 2010).

Possums, Rattus spp. and hedgehogs are known to prey upon Powelliphanta snails in forests, but there is no direct evidence for predation on high-altitude Powelliphanta. Alpine-dwelling Powelliphanta are currently considered less vulnerable to the impacts of most mammalian predators relative to their congeners from forested areas, due to their smaller size and reduced conspicuousness (K. Walker, DOC Nelson, pers. comm; Meads et al. 1984; Walker 2003).

It is unknown if invertebrates form an important component of the diet of feral cats in alpine areas. Invertebrates, particularly orthopterans and coleopterans, are commonly eaten by cats, especially kittens, though contribute little mass in cat diet overall (Gillies 2001; Harper 2005b). Some authors have suggested that in tussock grassland habitat, cats may consume more alternative prey such as invertebrates when rabbits or rodents are scarce, or when kittens have not yet developed the hunting skills to catch rabbits (Pierce 1987; Norbury et 
al. 1998; Murphy et al. 2004). In alpine habitat, short-horned grasshopper (Acrididae) remains have been identified in feral cat scats along Bealey Spur in Arthurs Pass National Park (K. Weston, pers. obs.).

\section{Freshwater fish}

We found no reports of mammalian predation on freshwater fish in the alpine zone, which is not surprising given the paucity of research on alpine fish. Anecdotes from lowland situations throughout New Zealand show that mammalian predators regularly take freshwater fish. For example, mice have been video-recorded consuming all eggs of inanga (Galaxias maculatus) from spawning sites (Baker 2006; Hickford et al. 2010), and mice along with Rattus spp., hedgehogs and stoats are likely to feed on nests of other galaxids such as shortjawed, banded and giant kōkopu ( $G$. postvectis, $G$. fasciatus, G. argenteus) (D. Jack, DOC Dunedin, pers. comm.; Allibone \& Caskey 2000; Charteris et al. 2003). Rattus spp. have been observed taking freshwater mussels (Hydridella menziesii) (M. Brady, DOC Napier, pers. comm.; P. Ravenscroft, DOC Dunedin, pers. comm.). Cats have been seen taking eels (Anguilla spp.) and kōkopu (Galaxias spp.) in Northland (P. Warren, DOC Wellington, pers. comm.) and koi carp (Cyprinus carpio) at Whangamarino wetland when water levels decline (M. Brady, pers. comm.). Stoats have been recorded eating banded kōkopu on Banks Peninsula (S. Bowie, DOC Christchurch, pers. comm.) and dragging live and freshly dead eels and a live lamprey (Geotria australis) along tracks, presumably after catching them (Waikato, Arthur's Pass and the West Coast; C. Annandale, DOC Hamilton, pers. comm.; C. Golding, DOC Motueka, pers. comm.; COD, pers. obs.). Fish were a regular dietary item of stoats at Okarito and Te Urewera, present in up to $5 \%$ of gut samples in some seasons
(Rudolph 1999; Murphy et al. 2008). Stoats have also been seen taking freshwater crayfish (Murphy et al. 2008; B. Rance, DOC Invercargill, pers. comm.). Ferrets have been observed catching spawning sockeye salmon (Oncorhynchus nerka) in the Canterbury high country (P. Ravenscroft, DOC Dunedin, pers. comm.) and scavenging stranded brown trout (Salmo trutta) on the Lindis River (Fish \& Game Cromwell, pers. comm.). Based on these observations, we suggest that alpine predators are likely to prey upon freshwater fish at times.

\section{Interactions with other threats - an alpine conceptual model}

Conceptual ecosystem modelling provides a framework for deciding on and declaring clear and specific conservation targets for ecosystem management (Margoluis et al. 2009). Although the focus of our review is on threats posed by introduced mammalian predators, conceptual modelling exposes interactions among threats and information gaps when there is a high degree of uncertainty about specific pressures (c.f. more data rich approaches; e.g. Price \& Gawne 2009; Ramsey \& Norbury 2009). We developed a conceptual model to illustrate the major threats to alpine biodiversity, how they are likely to interact with predation, and their relationships to different biodiversity conservation objectives, other ecosystem drivers, and associated management actions, as a way of identifying priority research needs (Fig. 3; based on two workshops).

For alpine ecosystems, broad conservation targets revolve around restoring browse sensitive flora, predator sensitive fauna, and community structure and function (Fig. 3). Although trajectories for these targets are unknown, conceptually they encompass increasing the condition, richness, and/or abundance

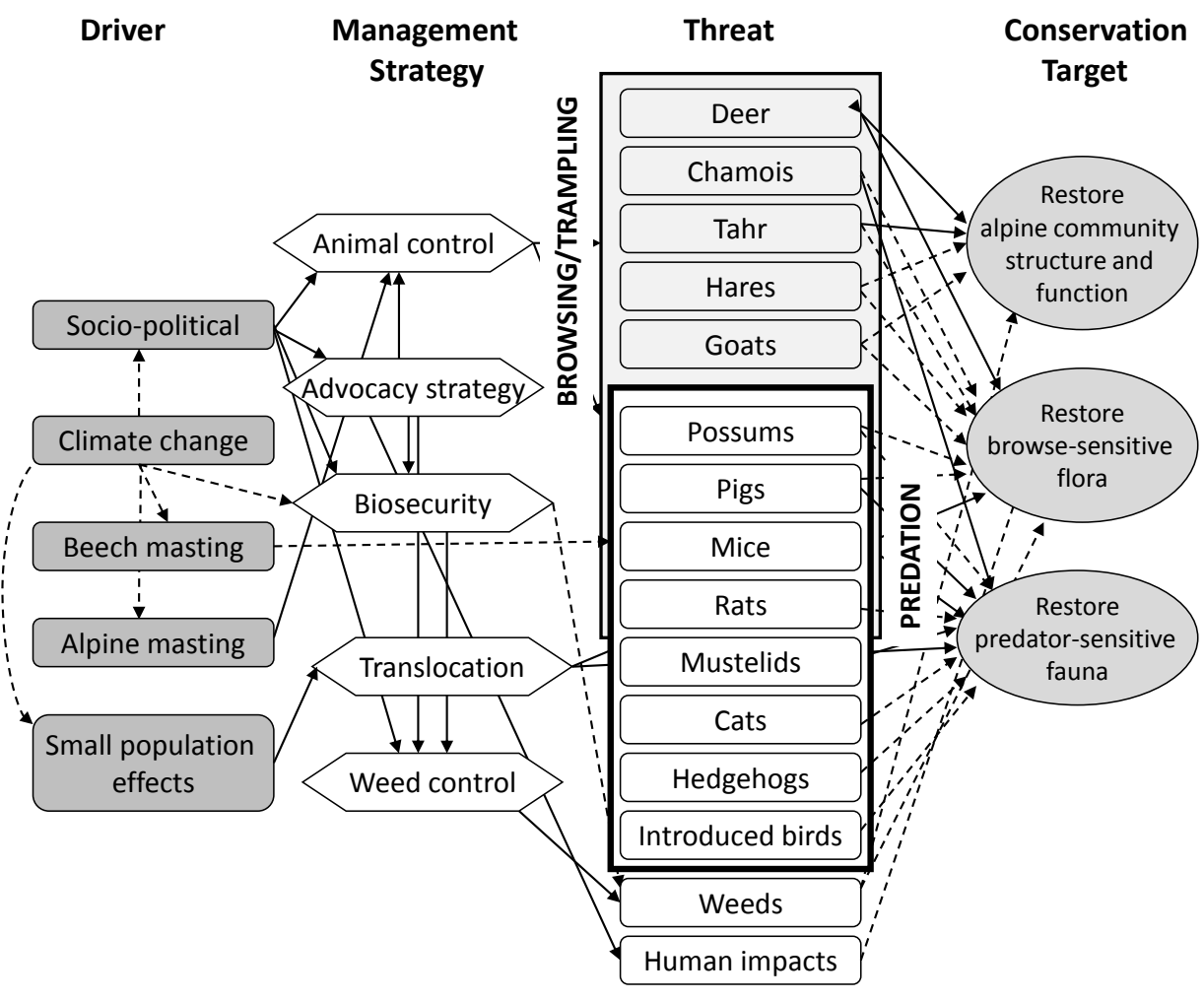

Figure 3. Conceptual model for threats to alpine biodiversity in New Zealand, where a Conservation Target $=$ a specific target or outcome that needs to be achieved to enhance ecological integrity; Threat $=$ a major threat to achieving the conservation target or targets; Management Strategy $=$ a management strategy to alleviate threats; and Driver $=$ major ecological or social drivers influencing threats to the ecosystem or ability to manage threats. Arrows depict cause and effect relationships between different components. Solid arrows indicate the relationship has been established or is well known, whereas dashed lines depict uncertainty, thus signalling priority research gaps that should be addressed before effective management strategies can be implemented. Under threats, the top box includes browsers/tramplers, whereas the bottom (solid lined) box lists predators, four of which also overlap the browsers/trampler box. 
of sensitive indicator species until they eventually reach a yet-to be-defined asymptote representative of a reference ecosystem (Matthews et al. 2009). The targets reflect thinking that is now common among many restoration ecologists in New Zealand. That is, an awareness of the profound effects of introduced browsers and mammalian predators on indigenous biodiversity and a broad aim to restore ecological integrity as much as is practicable (Atkinson 2001; Saunders \& Norton 2001).

The model identifies many potential threats to achieving biodiversity restoration targets in the alpine zone (Fig. 3). However, the numerous dashed lines in the model indicate our uncertainty about many relationships. For example, between 'browsers' and the 'restore community structure and function' and 'restore browse-sensitive flora' targets, the dashed lines indicate uncertainty about the absolute impacts of ungulates, possums and hares on regeneration, and the influence of rodents on seed predation. We consider the primary threats to alpine fauna to be mice and stoats (solid arrows; see earlier) but this review highlights uncertainty about the current importance of Rattus spp., cats, pigs, hedgehogs, and possums as predators in this ecosystem. There are other potential predators, such as introduced blackbirds (Turdus merula) and song thrushes (T. philomelos), which prey upon threatened snails at high altitude (K. Walker, DOC Nelson, pers. comm.) and whistling frogs (Litoria ewingii) which are likely to prey upon alpine invertebrates. Conversely, native avian predators are likely to be important natural predators, which should be recognised when restoring functioning ecosystems. Weed spread is a threat to restoring the integrity of alpine ecosystems in some locations (for example, Calluna vulgaris, Pinus contorta and Salix spp. in the central North Island, Juncus squarrosus in damp, low fertility sites, and some Hieracium spp. in alpine marble ecosystems; S. Moore, DOC Nelson, pers. comm.; R. Burns, DOC Rotorua, pers. comm.).

Whether there are interactions between browsers, mammalian predators and weeds that influence the intensity of these pressures is unknown, although such interactions are evident in dryland, braided river and forest ecosystems (Norbury et al. 2013; Tompkins et al. 2013; Pickerell et al. 2014). In addition to pests, human impacts have in the past impacted on alpine areas through intensive farming and burning, and contemporary threats may impact local alpine sites directly, for example, through the development of ski fields, wind farms and alpine roads, and by lighting fires.

There is also uncertainty about the importance of some of the key drivers of threats in the alpine zone. The primary drivers are likely to include beech masting and consequent fluctuations in pest densities in adjacent forests that may have flow-on effects to pest densities above the timberline. The relationship between beech masting, subsequent plagues of rodents and stoats, and increased predation on sensitive species is well documented in forests (King 1983; Murphy \& Dowding 1995; O’Donnell \& Phillipson 1996; O’Donnell et al. 1996; Dilks et al. 2003), but the form of such interactions in the alpine zone is unclear. Similarly, periodic heavy seeding of tussocks, and the fruiting and seeding of other alpine plants, may also drive predator cycles above the timberline, though only one study to date has documented these relationships (Wilson et al. 2006; Wilson \& Lee 2010). Thus, there are several questions around the way in which predation risk might vary in time and space, how impacts might vary among vulnerable species, interactions among guilds of alpine predators, and impacts of mammalian predators relative to other environmental threats. For example, it has been postulated that predation risk will increase under future climate change scenarios because ship rats will invade high altitude areas and likely irrupt in numbers more frequently (Christie 2014). Socio-political factors are also major drivers, particularly as they influence the acceptability of different toxins for pest control and of different ground or aerial hunting strategies for ungulates.

Small-population processes refer to genetic and random stochastic events that have disproportionate impacts on viability of populations once they become very small (Lande 1993). Diseases can become more significant when populations are small and under stress. Disease issues in the model specifically reflect the presence of the viral Psittacine beak and feather disease (PBFD), which affects parrots in New Zealand forests, although its potential influence on alpine kea is uncertain (Massaro et al. 2012). There is also strong evidence that increasing temperatures are associated with expanding mosquito-borne diseases into higher altitude areas worldwide (Epstein et al. 1998). In Hawaii, avian malaria has devastated the native avifauna and it is predicted that warming temperatures will enable mosquito vectors to invade into the few remaining mountain refugia of several endangered species (van Riper III et al. 1986; Benning et al. 2002; Freed et al. 2005). Vectors of avian malaria in New Zealand are known to be extending in range, signalling a real risk of disease emergence in alpine ecosystems with further climatic warming (Tompkins \& Gleeson 2006; Cross 2014). Extreme weather events, in the form of markedly higher or lower winter temperatures, adversely affect survival of birds and bats in adjacent forests (Dilks 1999; Pryde et al. 2005), so may also influence survival of alpine species. Extreme events are being reflected in the duration and extent of the winter snow pack and increased erosion (McGlone \& Walker 2011).

We identified five areas where management interventions are likely to be required (Fig. 3). The primary strategy is to control pests directly through animal and weed control, with a second management strategy being translocations for reintroducing key species (e.g. kiwi) to some areas, despite the poor understanding of species loss in the alpine zone. Although aerial hunting techniques are well developed for ungulate browsers (Rose \& Platt 1987), they are absent for hare control. There is also uncertainty about whether 'best practice' predator control would be effective in the alpine zone. Current 'best practice' for stoat control in forests involves intensive trapping (O’Donnell et al. 1996; Dilks et al. 2003) and/or secondary poisoning where Rattus spp. are the primary vector of the toxin 1080 (Gillies \& Pierce 1999; Murphy et al. 1999). However, whether such techniques are effective in the alpine zone is unknown. The practicality of large-scale trapping above the timberline is limited because of difficulties in servicing traps at appropriate densities in rugged terrain with seasonal access. Capitalising on secondary poisoning via aerial application of toxins is likely to be more cost effective than trapping, but suitable vectors may not be present in sufficiently predictable numbers. Ship rats, which are the primary vector for poisoning stoats in forests, are rare at higher altitudes and above the timberline (Innes 2005b; Efford et al. 2006). Mice would be likely vectors for secondary poisoning in alpine areas when their densities are high, though whether mice can act as a vector for secondary poisoning of stoats on a large scale remains poorly understood. Other food sources may be equally important as vectors, especially in low rodent years (e.g. wētā, Smith et al. 2008; or perhaps hares). New toxins, such as para-aminopropiophenone (PAPP) for controlling stoats (Dilks et al. 2011), have potential to solve 
some of the challenges of predator control in the alpine zone (although development of a bait matrix for aerial delivery and regulatory approval are both required in this case).

The role of mice as alpine predators, and therefore the importance of controlling mice, is also uncertain. While there are records of mice preying on invertebrates and rock wren, their importance relative to other threats is unknown. Further, it has often been postulated that mice may compete with native fauna for food, though empirical evidence for such competition is lacking (Wilson et al. 2006). Understanding the impacts of mice and factors that influence variation in their numbers in space and time are fundamental research needs. It is likely that mouse numbers vary considerably seasonally, annually and among different alpine habitats (Wilson et al. 2006; Wilson \& Lee 2010). There is some evidence that periodic heavy seeding of tussocks (Kelly et al. 2000; Wilson \& Lee 2010) and potentially other alpine plants (Clarke 1968) strongly influences mouse cycles above the timberline. However, it is not known if best practice toxin applications could control mice, which appear to have different sensitivities to toxins compared with ship rats and potentially reach higher densities (J. Kemp, DOC Nelson, pers. comm.).

\section{Conclusions}

A wide range of introduced mammalian predators occupy the alpine zone of New Zealand. Although there are examples of these predators killing alpine invertebrates, lizards and birds, the impact of predation on population viability of these taxa is unknown. The strongest evidence for unsustainable impacts comes from a few relatively well-studied threatened bird species (takahē, rock wren and kiwi). While the precise impacts of mammalian predators on the long-term viability of threatened species have not been evaluated, anecdotal evidence suggests that predation is a serious threat, warranting predator control.

There is substantial diversity and pattern within and between alpine communities throughout New Zealand, largely driven by differences in climatic conditions affected by latitude, local topography, substrate patterns, west-east climatic gradients and geological history. Thus, the few studies indicating impacts of predators require replication across alpine ecosystems if we are to understand fully the threats and how to manage them. There is also little understanding of how food resources, climate change, and pest densities in adjacent lower altitude forest drive alpine predator populations. Understanding these factors is important before appropriate pest management techniques can be developed and initiated at the right scale. Future research should focus on predicting when and where mammalian predators impact on populations, furthering our understanding of the alpine predator guild, particularly through adaptive management experiments, and exploring interactions with other threats. Development of robust and logistically feasible monitoring methods for predators and their prey above the timberline is also urgently required.

\section{Acknowledgements}

Thank you to Rebecca Jackson, Dan Palmer, David Webb and David West for assisting with reviewing literature and databases, Richard Earl and Shaun Weston for GIS mapping of NZ alpine zones, and Paul van Dam-Bates for assistance with ggplot2. Thanks to Chris Annandale, Matt Brady, Sjaan
Bowie, Rhys Burns, Jan Clayton-Greene, Daniel Jack, Natasha Petrove, Pete Ravenscroft, Kath Walker and Paula Warren for anecdotal observations of predation. We also thank Polly Bulling, Rhys Burns, Richard Earl, Eric Edwards, Terry Greene, Gerard Hill, James Holborow, Lynn Huggins, Fatima Iftiker, John Leathwick, Simon Moore, Grant Norbury, Emmanuel Oyston, Moira Pryde, Brian Rance, James Reardon, and Lindsay Wilson for contributing to our conceptual modelling workshops. We thank DOC Taranaki, Nelson Lakes, Haast and Te Anau for providing examples of alpine trapping data. We also thank Eric Edwards, Warren Chinn, Rod Hitchmough and Marieke Lettink for comments on earlier versions of this manuscript. Lastly, we thank Deb Wilson, Des Smith and an anonymous referee for their constructive comments and advice during the review process.

\section{References}

Allibone RM, Caskey D 2000. Timing and habitat of koaro (Galaxias brevipinnis) spawning in streams draining $\mathrm{Mt}$ Taranaki, New Zealand. New Zealand Journal of Marine and Freshwater Research 34: 593-595.

Arensburger P, Simon C, Holsinger K 2004. Evolution and phylogeny of the New Zealand cicada genus Kikihia Dugdale (Homoptera: Auchenorrhyncha: Cicadidae) with reference to the origin of the Kermadec and Norfolk Islands' species. Journal of Biogeography 31: 1769-1783.

Atkinson IAE 2001. Introduced mammals and models for restoration. Biological Conservation 99: 81-96.

Atkinson IAE, Towns DR 2005. Kiore. In: King CM ed. The handbook of New Zealand mammals. Melbourne, Australia, Oxford University Press. Pp. 159-174.

Baber M, Brejaart R, Babbitt K, Lovegrove T, Ussher G 2009. Response of non-target native birds to mammalian pest control for kokako (Callaeas cinerea) in the Hunua Ranges, New Zealand. Notornis 56: 176-182.

Baker CF 2006. Predation of inanga (Galaxias maculatus) eggs by field mice (Mus musculus). Journal of the Royal Society of New Zealand 36: 143-147.

Basse B, McLennan J, Wake G 1999. Analysis of the impact of stoats, Mustela erminea, on northern brown kiwi, Apteryx mantelli, in New Zealand. Wildlife Research 26: 227-237.

Batcheler C 1967. Preliminary observations of alpine grasshoppers in a habitat modified by deer and chamois. Proceedings of the New Zealand Ecological Society. Pp. 15-26.

Beauchamp A 2009. Distribution and habitat use by New Zealand pipits (Anthus n. novaeseelandiae) on the Volcanic Plateau. Notornis 56: 183-189.

Bell TP, Patterson GB 2008. A rare alpine skink Oligosoma pikitanga n. sp. (Reptilia: Scincidae) from Llawrenny Peaks, Fiordland, New Zealand. Zootaxa: 57-68.

Benning TL, LaPointe D, Atkinson CT, Vitousek PM 2002. Interactions of climate change with biological invasions and land use in the Hawaiian Islands: modeling the fate of endemic birds using a geographic information system. Proceedings of the National Academy of Sciences 99: 14246-14249.

Berry CJ 1999. Potential interactions of hedgehogs with North Island brown kiwi at Boundary Stream Mainland Island. Wellington, New Zealand, Department of Conservation. $22 \mathrm{p}$.

Bigelow RS 1967. Grasshoppers of New Zealand: their 
taxonomy and distribution. Christchurch, University of Canterbury Press. $60 \mathrm{p}$.

BischoffM2008. Pollination ecology of the New Zealand alpine flora. Unpublished $\mathrm{PhD}$ thesis, University of Heidelberg, Heidelberg, Germany. 266 p.

Bischoff M, Campbell DR, Lord JM, Robertson AW 2013. The relative importance of solitary bees and syrphid flies as pollinators of two outcrossing plant species in the New Zealand alpine. Austral Ecology 38: 169-176.

Brockie R 1975. Distribution and abundance of the hedgehog (Erinaceus europaeus) L. in New Zealand, 1869-1973. New Zealand Journal of Zoology 2: 445-462.

Brown K, Innes J, Shorten R 1993. Evidence that possums prey on and scavenge birds' eggs, birds and mammals. Notornis 40: 169-177.

Buckley TR, Simon C 2007. Evolutionary radiation of the cicada genus Maoricicada Dugdale(Hemiptera: Cicadoidea) and the origins of the New Zealand alpine biota. Biological Journal of the Linnean Society 91: 419-435.

Buckley TR, Krosch M, Leschen RAB 2015. Evolution of New Zealand insects: summary and prospectus for future research. Austral Entomology 54: 1-27.

Burns K 2006. Weta and the evolution of fleshy fruits in New Zealand. New Zealand Journal of Ecology 30: 405-406.

Chamberlain DE, Negro M, Caprio E, Rolando A 2013. Assessing the sensitivity of alpine birds to potential future changes in habitat and climate to inform management strategies. Biological Conservation 167: 127-135.

Charteris SC, Allibone RM, Death RG 2003. Spawning site selection, egg development, and larval drift of Galaxias postvectis and G. fasciatus in a New Zealand stream. New Zealand Journal of Marine and Freshwater Research 37: 493-505.

Chen I-C, Hill JK, Ohlemüller R, Roy DB, Thomas CD 2011. Rapid range shifts of species associated with high levels of climate warming. Science 333: 1024-1026.

Choquenot D, Ruscoe WA 2000. Mouse population eruptions in New Zealand forests: the role of population density and seedfall. Journal of Animal Ecology 69: 1058-1070.

Choquenot D, Ruscoe WA, Murphy E 2001. Colonisation of new areas by stoats: time to establishment and requirements for detection. New Zealand Journal of Ecology 25: 83-88.

Christie J 2014. Adapting to a changing climate: a proposed framework for the conservation of terrestrial native biodiversity in New Zealand. Wellington, New Zealand. Department of Conservation. $23 \mathrm{p}$.

Christie J, Wilson P, Taylor R, Elliott G 2017. Altitudinal variation in ship rat (Rattus rattus) capture patterns, $\mathrm{Mt}$ Misery, New Zealand. New Zealand Journal of Ecology 41: 113-119.

Cieraad E, McGlone MS 2014. Thermal environment of New Zealand's gradual and abrupt treeline ecotones. New Zealand Journal of Ecology 38: 12-25.

Clarke C 1968. Flowering periods of alpine plants at Cupola Basin, Nelson, New Zealand. New Zealand Journal of Botany 6: 205-220.

Clarke C 1970. Observations on population, movements and food of the kea (Nestor notabilis). Notornis 17: 105-114.

Clout M, Ericksen K 2000. Anatomy of a disastrous success: the brushtail possum as an invasive species. In: Montague TL ed. The brushtail possum: biology, impact and management of an introduced marsupial. Lincoln, New Zealand, Manaaki Whenua Press. Pp. 1-9.

Coleman JD, Gillman A, Green W 1980. Forest patterns and possum densities within podocarp/mixed hardwood forests on Mt Bryan O'Lynn, Westland. New Zealand Journal of Ecology 3: 69-84.

Collins G, Charleston W 1979. Studies on Sarcocystis species: 1. Feral cats as definitive hosts for sporozoa. New Zealand Veterinary Journal 27: 80-84.

Connor HE 1991. Chionochloa Zotov (Gramineae) in New Zealand. New Zealand Journal of Botany 29: 219-282.

Cowan P 2005. Brushtail possum. In: King CM ed. The handbook of New Zealand mammals. Auckland, Oxford University Press. Pp. 56-80.

Craw RC 1999. Molytini (Insecta: Coleoptera: Curculionidae: Molytinae). Lincoln, New Zealand, Manaaki Whenua Press. 68 p.

Cross C 2014. A study into the mosquito and avian fauna at Nelson Lakes National Park (NLNP): a preliminary assessment for avian malaria management. A report submitted in partial fulfilment of the Post-graduate Diploma in Wildlife Management, University of Otago, Dunedin. 25 p.

Crouchley D 1994. Takahe recovery plan(Porphyrio [Notornis] mantelli). Wellington, New Zealand, Threatened Species Unit, Department of Conservation. $47 \mathrm{p}$.

Cruz J, Pech RP, Seddon PJ, Cleland S, Nelson D, Sanders MD, Maloney RF 2013. Species-specific responses by ground-nesting Charadriiformes to invasive predators and river flows in the braided Tasman River of New Zealand. Biological Conservation 167: 363-370.

Cuthbert RJ 2001. Conservation and ecology of Hutton's shearwater (Puffinus huttoni). Conservation Advisory Notes 355. Wellington, Department of Conservation. 35 p.

Cuthbert RJ 2002. The role of introduced mammals and inverse density-dependent predation in the conservation of Hutton's shearwater. Biological Conservation 108: 69-78.

Cuthbert RJ, Davis LS 2002. Adult survival and productivity of Hutton's shearwaters. Ibis 144: 423-432.

Cuthbert RJ, SommerE2002. Home range, territorial behaviour and habitat use of stoats (Mustela erminea) in a colony of Hutton's shearwater (Puffinus huttoni), New Zealand. New Zealand Journal of Zoology 29: 149-160.

Cuthbert RJ, Sommer E, Davis LS 2000. Seasonal variation in the diet of stoats in a breeding colony of Hutton's shearwaters. New Zealand Journal of Zoology 27: 367-373.

Daniel M, Williams G 1984. A survey of the distribution, seasonal activity and roost sites of New Zealand bats. New Zealand Journal of Ecology 7: 9-25.

Dilks P 1999. Recovery of a mohua (Mohoua ochrocephala) population following predator control in the Eglinton Valley, Fiordland, New Zealand. Notornis 46: 323-332.

Dilks P, Willans M, Pryde M, Fraser I 2003. Large scale stoat control to protect mohua (Mohoua ochrocephala) and kaka (Nestor meridionalis) in the Eglinton Valley, Fiordland, New Zealand. New Zealand Journal of Ecology 27: 1-9.

Dilks P, Shapiro L, Greene T, Kavermann M, Eason C, Murphy E 2011. Field evaluation of para-aminopropiophenone (PAPP) for controlling stoats (Mustela erminea) in New Zealand. New Zealand Journal of Zoology 38: 143-150.

Dirnböck T, Essl F, Rabitsch W 2011. Disproportional risk for habitat loss of high-altitude endemic species under climate change. Global Change Biology 17: 990-996.

Dowding JE 1995. Research on New Zealand dotterels during the 1994-95 season. Wellington, Department of Conservation. $16 \mathrm{p}$. 
Dowding JE 1999. Past distribution and decline of the New Zealand dotterel (Charadrius obscurus) in the South Island of New Zealand. Notornis 46: 167-180.

Dowding JE, Murphy EC 1993. Decline of the Stewart Island population of the New Zealand dotterel. Notornis 40: 114.

Dowding JE, Murphy EC 2001. The impact of predation by introduced mammals on endemic shorebirds in New Zealand: a conservation perspective. Biological Conservation 99: 47-64.

Dragon S, Carey C, Martin K, Baumann R 1999. Effect of high altitude and in vivo adenosine $/(\beta)$-adrenergic receptor blockade on ATP and 2, 3BPG concentrations in red blood cells of avian embryos. Journal of Experimental Biology 202: 2787-2795.

Dugdale J, Fleming C 1978. New Zealand cicadas of the genus Maoricicada (Homoptera: Tibicinidae). New Zealand Journal of Zoology 5: 295-340.

Dwyer PD 1962. Studies on the two New Zealand bats. Zoology Publications. Victoria University, Wellington, New Zealand.

Edmonds H 2015. Taxon plan for northern and southern Fiordland tokoeka (Apteryx australis australis). Strategic plan for the recovery of northern and southern Fiordland tokoeka, for the period 2015-2025 and beyond. Te Anau, New Zealand, Department of Conservation. 25 p.

Efford MG, Fitzgerald BM, Karl BJ, Berben PH 2006. Population dynamics of the ship rat Rattus rattus $\mathrm{L}$. in the Orongorongo Valley, New Zealand. New Zealand Journal of Zoology 33: 273-297.

Elliott G, Kemp J 2004. Effect of hunting and predation on kea, and a method of monitoring kea populations. Results of kea research on the St. Arnaud Range. DOC Science Internal Series 181: 1-17.

Epstein PR, Diaz HF, Elias S, Grabherr G 1998. Biological and physical signs of climate change: focus on mosquitoborne diseases. Bulletin of the American Meteorological Society 79: 409 .

Fitzgerald B, Daniel M, Fitzgerald A, Karl B, Meads M, Notman P 1996. Factors affecting the numbers of house mice (Mus musculus) in hard beech (Nothofagus truncata) forest. Journal of the Royal Society of New Zealand 26: 237-249.

Flux JEC 1967. Hare numbers and diet in an alpine basin in New Zealand. Proceedings of the New Zealand Ecological Society 14: 27-33.

Franzén M, Molander M 2012. How threatened are alpine environments? A cross taxonomic study. Biodiversity and Conservation 21: 517-526.

Fraser K, Cone J, Whitford E2000. Arevision of the established ranges and new populations of 11 introduced ungulate species in New Zealand. Journal of the Royal Society of New Zealand 30: 419-437.

Freed LA, Cann RL, Goff ML, Kuntz WA, Bodner GR 2005. Increase in avian malaria at upper elevation in Hawai' $i$. The Condor 107: 753-764.

Frey JK, Calkins MT 2014. Snow cover and riparian habitat determine the distribution of the short-tailed weasel (Mustela erminea) at its southern range limits in arid western North America. Mammalia 78: 45-56.

Gardner E 2010. An investigation into the altitudinal ecology of the Haast Tokoeka Kiwi (Apteryx australis 'Haast') and implications for conservation management. Unpublished MSc thesis, University College London, London, UK. 84 p.

Gibbs GW 1980. New Zealand butterflies: identification and natural history. Auckland, New Zealand, Collins. 207 p. Gibbs GW 1998. Why are some weta (Orthoptera: Stenopelmatidae) vulnerable yet others are common? Journal of Insect Conservation 2: 161-166.

Gibbs GW 1999. Four new species of giant weta, Deinacrida (Orthoptera:Anostostomatidae: Deinacridinae) from New Zealand. Journal of the Royal Society of New Zealand 29: 307-324.

Gillies C 2001. Advances in New Zealand mammalogy 1990-2000: house cat. Journal of the Royal Society of New Zealand 31: 205-218.

Gillies CA, Fitzgerald BM 2005. Feral cat. In: King CM ed. The handbook of New Zealand mammals. Melbourne, Oxford University Press. Pp. 308-327.

Gillies CA, Pierce RJ 1999. Secondary poisoning of mammalian predators during possum and rodent control operations at Trounson Kauri Park, Northland, New Zealand. New Zealand Journal of Ecology 23: 183-192.

Gillies CA, Williams D 2013. DOC tracking tunnel guide v2.5.2: using tracking tunnels to monitor rodents and mustelids. Hamilton, New Zealand, Department of Conservation.

Glen AS, Byrom AE, Pech RP, Cruz J, Schwab A, Sweetapple PJ, Yockney I, Nugent G, Coleman M, Whitford J 2012. Ecology of brushtail possums in a New Zealand dryland ecosystem. New Zealand Journal of Ecology 36: 29-37.

Goldberg J, Trewick SA, Paterson AM 2008. Evolution of New Zealand's terrestrial fauna: a review of molecular evidence. Philosophical Transactions of the Royal Society B: Biological Sciences 363: 3319-3334.

Goodman JM, Dunn NR, RavenscroftPJ,Allibone RM, Boubee JA, DavidBO, Griffiths M, Ling N, Hitchmough RA, Rolfe JR 2013. Conservation status of New Zealand freshwater fish, 2013. NZ Threat Classification Series 7. Wellington, New Zealand, Department of Conservation. $12 \mathrm{p}$.

Greer AL, Gajdon GK, Nelson XJ 2015. Intraspecific variation in the foraging ecology of kea, the world's only mountainand rainforest-dwelling parrot. New Zealand Journal of Ecology 39: 254-261.

Harding MA 1990. Observations of fruit eating by blue duck. Notornis 37: 150-152.

Harding MA 1994. Blue duck dispersal at Arthur's Pass. Notornis 41: 293-295.

Harper GA 2005a. Heavy rimu (Dacrydium cupressinum) mast seeding and rat (Rattus spp.) population eruptions on Stewart Island/Rakiura. New Zealand Journal of Zoology 32: $155-162$.

Harper GA 2005b. Numerical and functional response of feral cats (Felis catus) to variations in abundance of primary prey on Stewart Island (Rakiura), New Zealand. Wildlife Research 32: 597-604.

Hegg D, Greaves G, Maxwell JM, Mackenzie DI, Jamieson IG 2012. Demography of takahe (Porphyrio hochstetteri) in Fiordland: environmental factors and management affect survival and breeding success. New Zealand Journal of Ecology 36: 75-89.

Hickford MJ, Cagnon M, Schiel DR 2010. Predation, vegetation and habitat-specific survival of terrestrial eggs of a diadromous fish, Galaxias maculatus (Jenyns, 1842). Journal of Experimental Marine Biology and Ecology 385: 66-72.

Hickling GJ, Forsyth DM 2000. Assessment of the extent of alpine areas being utilised as possum habitat in Westland. Lincoln, New Zealand, Lincoln University. 10 p. 
Hickson RE, Moller H, Garrick AS 1986. Poisoning rats on Stewart Island. New Zealand Journal of Ecology 9: 111-121.

Higgins P, Peter J, Cowling S 2006. Handbook of Australian, New Zealand and Antarctic birds. Volume 7: boatbill to starlings. Melbourne, Australia, Oxford University Press. 420 p.

Hitchmough R, Barr B, Lettink M, Monks J, Reardon J, Tocher M, van Winkel D, Rolfe J 2016. Conservation status of New Zealand reptiles, 2015. New Zealand Threat Classification Series 17. Wellington, New Zealand, Department of Conservation. $14 \mathrm{p}$.

Holdaway RN 1989. New Zealand's pre-human avifauna and its vulnerability. New Zealand Journal of Ecology 12: 11-25.

Hope K 2014. Investigation into the population plateau of the southern New Zealand dotterel. Post-graduate Diploma in Wildlife Management, University of Otago, Dunedin, New Zealand. 28 p.

Horrocks M, Costa D, Wallace R, Gardner R, Kondo R 2004. Plant remains in coprolites: diet of a subalpine moa (Dinornithiformes) from southern New Zealand. Emu 104: 149-156.

Innes J 2005a. Norway rat. In: King CM ed. The handbook of New Zealand mammals. Melbourne, Australia, Oxford University Press. Pp. 174-187.

Innes J 2005b. Ship rat. In: King CM ed. The handbook of New Zealand mammals. Melbourne, Australia, Oxford University Press. Pp. 187-204.

Innes J, Kelly D, Overton JM, Gillies C 2010. Predation and other factors currently limiting New Zealand forest birds. New Zealand Journal of Ecology 34: 86-114.

Jackson J 1963. The nesting of keas. Notornis 10: 319-326.

Jackson J 1969. What do keas die of? Notornis 16: 33-44.

Jones C, Sanders M 2005. European hedgehog. In: King CM ed. The handbook of New Zealand mammals. Melbourne, Australia, Oxford University Press. Pp. 81-94.

Jones C, Moss K, Sanders M 2005. Diet of hedgehogs (Erinaceus europaeus) in the upper Waitaki Basin, New Zealand: implications for conservation. New Zealand Journal of Ecology 29: 29-35.

Jones C, Norbury G, Bell T 2013. Impacts of introduced European hedgehogs on endemic skinks and weta in tussock grassland. Wildlife Research 40: 36-44.

Kelly D, Harrison AL, Lee WG, Payton IJ, Wilson PR, Schauber EM 2000. Predator satiation and extreme mast seeding in 11 species of Chionochloa (Poaceae). Oikos 90:477-488.

Keye C, Roschak C, Ross J 2011. Summer home range size and population density of great spotted kiwi (Apteryx haastii) in the North Branch of the Hurunui River, New Zealand. Notornis 58: 22-30.

King CM 1983. The relationship between beech Nothofagus sp. seedfall and populations of mice Mus musculus, and the demographic and dietary responses of stoats (Mustela erminea); in three New Zealand forests. Journal of Animal Ecology 52: 414-466.

King CM 2005. The handbook of New Zealand mammals. Melbourne, Australia, Oxford University Press. 610 p.

King CM, Moller H 1997. Distribution and response of rats Rattus rattus, $R$. exulans to seedfall in New Zealand beech forests. Pacific Conservation Biology 3: 143-155.

King CM, Murphy EC 2005. Stoat. In: King CM ed. The handbook of New Zealand mammals. Melbourne, Australia, Oxford University Press. Pp. 261-287.

King CM, Powell RA2007. The natural history of weasels and stoats: ecology, behavior, and management. New York, USA, Oxford University Press. 464 p.

King CM, Flux M, Innes JG, Fitzgerald BM 1996. Population biology of small mammals in Pureora Forest Park: 1. Carnivores (Mustela erminea, M. furo, M. nivalis, and Felis catus). New Zealand Journal of Ecology 20: 241-251.

Laiolo P, Dondero F, Ciliento E, Rolando A2004. Consequences of pastoral abandonment for the structure and diversity of the alpine avifauna. Journal of Applied Ecology 41: 294-304.

Lande R 1993. Risks of population extinction from demographic and environmental stochasticity and random catastrophes. American Naturalist 142: 911-927.

Larsen H, Burns KC 2012. Seed dispersal effectiveness increases with body size in New Zealand alpine scree weta (Deinacrida connectens). Austral Ecology 37: 800-806.

Lavers R, Mills J 1978. Stoat studies in the Murchison Mountains, Fiordland. Seminar on the takahe and its habitat. Wildlife Service, Department of Internal Affairs, Invercargill.

Lavers R, Lee W, Wilson J, Mills J 1983. Foods of red deer in the Murchison Mountains, Fiordland, New Zealand. New Zealand Journal of Ecology 6: 151-152.

Lawrence MH 1997. The importance of lizards to seed dispersal of native montane fleshy fruits, Canterbury, New Zealand. Unpublished MSc thesis, University of Canterbury, Christchurch, New Zealand. 78 p.

Lee WG, Wood JR, Rogers GM 2010. Legacy of aviandominated plant-herbivore systems in New Zealand. New Zealand Journal of Ecology 34: 28-47.

Leschen R, Marris J, Emberson R, Nunn J, Hitchmough R, Stringer I 2012. The conservation status of New Zealand Coleoptera. New Zealand Entomologist 35: 91-98.

Lettink M, Norbury G, CreeA, Seddon PJ, Duncan RP, Schwarz CJ 2010. Removal of introduced predators, but not artificial refuge supplementation, increases skink survival in coastal duneland. Biological Conservation 143: 72-77.

MacDonald MA, Bolton M 2008. Predation on wader nests in Europe. Ibis 150: 54-73.

Margoluis R, Stem C, Salafsky N, Brown M 2009. Using conceptual models as a planning and evaluation tool in conservation. Evaluation and Program Planning 32: $138-147$.

Mark AF, Adams NM 1995. New Zealand alpine plants. Auckland, Godwit Publishing Ltd. 269 p.

Mark A, Dickinson K 1997. New Zealand alpine ecosystems. In: Wielgolaski FE, Goodall DW eds. Polar and alpine tundra. Ecosystems of the world. Amsterdam, Elsevier. Pp. 311-346.

MarkAF, Dickinson KJ, Hofstede RG 2000.Alpine vegetation, plant distribution, life forms, and environments in a perhumid New Zealand region: oceanic and tropical high mountain affinities. Arctic, Antarctic, and Alpine Research 32: $240-254$.

Massaro M, Ortiz-Catedral L, Julian L, Galbraith JA, Kurenbach B, Kearvell J, Kemp J, van Hal J, Elkington S, Taylor G 2012. Molecular characterisation of beak and feather disease virus (BFDV) in New Zealand and its implications for managing an infectious disease. Archives of Virology 157: 1651-1663.

Matthews JW, Spyreas G, Endress AG 2009. Trajectories of vegetation-based indicators used to assess wetland restoration progress. Ecological Applications 19: 2093-2107. 
Maxwell JM 2001. Fiordland takahe: population trends, dynamics and problems. In: Lee W, Jamieson I eds. The takahe: fifty years of conservation management and research. Dunedin, University of Otago Press. Pp. 61-79.

Maxwell JM, Christie J 2005. Takahe egg and chick mortality field study-Murchison Mountains, Fiordland 1997-2001. Unpublished Report. Te Anau, New Zealand, Department of Conservation.

McCulloch GA, Wallis GP, Waters JM 2009. Do insects lose flight before they lose their wings? Population genetic structure in subalpine stoneflies. Molecular Ecology 18: 4073-4087.

McCulloch GA, Wallis GP, Waters JM2010. Onset of glaciation drove simultaneous vicariant isolation of alpine insects in New Zealand. Evolution 64: 2033-2043.

McGlone MS, Walker S 2011. Potential effects of climate change on New Zealand's terrestrial biodiversity and policy recommendations for mitigation, adaptation and research. Science for Conservation 312. Wellington, New Zealand, Department of Conservation. $78 \mathrm{p}$.

McIlroy J 2005. Feral pig. In: King CM ed. The handbook of New Zealand mammals. Melbourne, Oxford University Press. Pp. 334-346.

McLellan I 1977. New alpine and southern Plecoptera from New Zealand, and a new classification of the Gripopterygidae. New Zealand Journal of Zoology 4: 119-147.

McLennan J, McCann T2002. Genetic variability, distribution and abundance of great spotted kiwi (Apteryx haastii). Science \& Research Internal Report. Wellington, Department of Conservation.

McLennan J, Potter M, Robertson H, Wake G, Colbourne R, Dew L, Joyce L, McCann A, Miles J, Miller P 1996. Role of predation in the decline of kiwi, Apteryx spp., in New Zealand. New Zealand Journal of Ecology 20: 27-35.

Meads MJ, Walker KJ, Elliott GP 1984. Status, conservation, and management of the land snails of the genus Powelliphanta (Mollusca: Pulmonata). New Zealand Journal of Zoology 11: 277-306.

Michelsen S 1982. Habitat requirements and feeding behaviour of the rock wren, Xenicus gilviventris in Mount Cook National Park, New Zealand. Post-Grad. Dip. Wildlife Management thesis, University of Otago, Dunedin, New Zealand. 104 p.

Michelsen-Heath S 1989. The breeding biology of the rock wren, Xenicus gilviventris, in the Murchison Mountains, Fiordland National Park, New Zealand. Unpublished MSc thesis, University of Otago, Dunedin, New Zealand. 105 p.

Mills JA, Mark AF 1977. Food preferences of takahe in Fiordland National Park, New Zealand, and the effect of competition from introduced red deer. The Journal of Animal Ecology 46: 939-958.

Mills JA, Lee WG, Mark AF, Lavers RB 1980. Winter use by takahe (Notornis mantelli) of the summer-green fern (Hypolepis millefolium) in relation to its annual cycle of carbohydrates and minerals. New Zealand Journal of Ecology 3: 131-137.

Miskelly CM, Walker KJ, Elliott GP 2006. Breeding ecology of three subantarctic snipes (genus Coenocorypha). Notornis 53: 361-374.

Morgan-Richards M, Gibbs GW 2001. A phylogenetic analysis of New Zealand giant and tree weta (Orthoptera: Anostostomatidae: Deinacrida and Hemideina) using morphological and genetic characters. Invertebrate Systematics 15: 1-12.
Morgan-Richards M, Trewick SA, Dunavan S 2008. When is it coevolution? The case of ground wētā and fleshy fruits in New Zealand. New Zealand Journal of Ecology 32: $108-112$.

Morris SJ 2003. Two new species of Sigaus from Fiordland, New Zealand (Orthoptera: Acrididae). New Zealand Entomologist 26: 65-74.

Murphy EC 1992. The effects of a natural increase in food supply on a wild population of house mice. New Zealand Journal of Ecology 16: 33-40.

Murphy EC, Dowding JE 1995. Ecology of the stoat in Nothofagus forest: home range, habitat use and diet at different stages of the beech mast cycle. New Zealand Journal of Ecology 19: 97-109.

Murphy EC, Clapperton BK, Bradfield PM, Speed HJ 1998. Effects of rat-poisoning operations on abundance and diet of mustelids in New Zealand podocarp forests. New Zealand Journal of Zoology 25: 315-328.

Murphy EC, Robbins L, Young JB, Dowding JE 1999. Secondary poisoning of stoats after an aerial 1080 poison operation in Pureora Forest, New Zealand. New Zealand Journal of Ecology 23: 175-182.

Murphy EC, Keedwell RJ, Brown KP, Westbrooke I 2004. Diet of mammalian predators in braided river beds in the central South Island, New Zealand. Wildlife Research 31: 631-638.

Murphy E, Maddigan F, Edwards B, Clapperton K 2008. Diet of stoats at Okarito Kiwi Sanctuary, South Westland, New Zealand. New Zealand Journal of Ecology 32: 41-45.

Newstrom L, Robertson A 2005. Progress in understanding pollination systems in New Zealand. New Zealand Journal of Botany 43: 1-59.

Nielsen SV, Bauer AM, Jackman TR, Hitchmough RA, Daugherty CH 2011. New Zealand geckos (Diplodactylidae): cryptic diversity in a post-Gondwanan lineage with trans-Tasman affinities. Molecular Phylogenetics and Evolution 59: 1-22.

Norbury GL, Norbury DC, Heyward RP 1998. Behavioral responses of two predator species to sudden declines in primary prey. The Journal of Wildlife Management 62: 45-58.

Norbury G, Byrom A, Pech R, Smith J, Clarke D, Anderson D, Forrester G 2013. Invasive mammals and habitat modification interact to generate unforeseen outcomes for indigenous fauna. Ecological Applications 23: 1707-1721.

Nugent G, Sweetapple P, Coleman J, Suisted P 2000. Possum feeding patterns: dietary tactics of a reluctant folivore. In: Montague TL ed. The brushtail possum: biology, impact and management of an introduced marsupial. Lincoln, Manaaki Whenua Press. Pp. 10-23.

O'Donnell CFJ 2001. Home range and use of space by Chalinolobus tuberculatus, a temperate rainforest bat from New Zealand. Journal of Zoology 253: 253-264.

O’Donnell CFJ, Dilks PJ 1994. Foods and foraging of forest birds in temperate rainforest, South Westland, New Zealand. New Zealand Journal of Ecology 18: 87-107.

O'Donnell CFJ, Hoare JM 2012. Quantifying the benefits of long-term integrated pest control for forest bird populations in a New Zealand temperate rainforest. New Zealand Journal of Ecology 36: 131-140.

O’Donnell CFJ, Phillipson SM 1996. Predicting the incidence of mohua predation from the seedfall, mouse, and predator fluctuations in beech forests. New Zealand Journal of Zoology 23: 287-293. 
O’Donnell CFJ, Dilks PJ, Elliott GP 1996. Control of a stoat (Mustela erminea) population irruption to enhance mohua (yellowhead) (Mohoua ochrocephala) breeding success in New Zealand. New Zealand Journal of Zoology 23: 279-286.

O’Donnell CFJ, Christie J, Corben C, Sedgeley JA, Simpson W 1999. Rediscovery of short-tailed bats (Mystacina sp.) in Fiordland, New Zealand: preliminary observations of taxonomy, echolocation calls, population size, home range, and habitat use. New Zealand Journal of Ecology 23: $21-30$.

O’Donnell CFJ, Reardon JT, Hoare JM 2011. Nectar feeding by rock wren (Xenicus gilviventris). Notornis 58: 46-47.

O’Donnell CFJ, Clapperton BK, Monks JM 2015. Impacts of introduced mammalian predators on indigenous birds of freshwater wetlands in New Zealand. New Zealand Journal of Ecology 39: 19-33.

Parkes JP, Forsyth DM 2008. Interspecific and seasonal dietary differences of Himalayan thar, chamois and brushtail possums in the central Southern Alps, New Zealand. New Zealand Journal of Ecology 32: 46-56.

Parkes JP, Tustin K, Stanley L 1978. The history and control of red deer in the takahe area, Murchison Mountains, Fiordland National Park. New Zealand Journal of Ecology 1: $145-152$.

Patrick BH, Patrick H 2012. Butterflies of the South Pacific. Dunedin, New Zealand, University of Otago Press. 239 p.

Patterson GB, Bell TP 2009. The Barrier skink Oligosoma judgei $\mathrm{n}$. Sp. (Reptilia: Scincidae) from the Darran and Takitimu Mountains, South Island, New Zealand. Zootaxa: 43-56.

Patthey P, Wirthner S, Signorell N, Arlettaz R 2008. Impact of outdoor winter sports on the abundance of a key indicator species of alpine ecosystems. Journal of Applied Ecology 45: 1704-1711.

Pickerell GA, O’Donnell CFJ, Wilson DJ, Seddon PJ 2014. How can we detect introduced mammalian predators in non-forest habitats? A comparison of techniques. New Zealand Journal of Ecology 38: 86-102.

Pierce RJ 1987. Predators in the Mackenzie Basin: their diet, population dynamics, and impact on birds in relation to the abundance and availability of their main prey (rabbits). Unpublished report. Wellington, New Zealand Wildlife Service, Department of Internal Affairs.

Poutu N, Warburton B 2005. Effectiveness of the DOC150, 200 and 250 traps for killing stoats, ferrets, Norway rats, ship rats, and hedgehogs. Unpublished Report. Lincoln, New Zealand.

Powlesland R, Merton DV, Cockrem JF 2006. A parrot apart: the natural history of the kakapo (Strigops habroptilus), and the context of its conservation management. Notornis 53:3.

Price A, Gawne B 2009. The development of wetland conceptual models for the semi-arid zone. Unpublished Report. Murray-Darling Freshwater Research Centre, Wodonga, Australia.

Primack RB 1978. Variability in New Zealand montane and alpine pollinator assemblages. New Zealand Journal of Ecology 1: 66-73.

Primack RB 1983. Insect pollination in the New Zealand mountain flora. New Zealand Journal of Botany 21: 317-333.

Pryde MA, O'Donnell CFJ, Barker RJ 2005. Factors influencing survival and long-term population viability of New Zealand long-tailed bats (Chalinolobus tuberculatus): implications for conservation. Biological Conservation 126: 175-185.

Ramløv H, Wharton DA, Wilson PW 1996. Recrystallization in a freezing tolerant Antarctic nematode, Panagrolaimus davidi, and an alpine weta, Hemideina maori (Orthoptera; Stenopelmatidae). Cryobiology 33: 607-613.

Ramsay G 1978. A review of the effect of rodents on the New Zealand invertebrate fauna. Wellington, New Zealand, Department of Lands and Survey.

Ramsey DS, Norbury GL 2009. Predicting the unexpected: using a qualitative model of a New Zealand dryland ecosystem to anticipate pest management outcomes. Austral Ecology 34: 409-421.

Reardon JT, Whitmore N, Holmes KM, Judd LM, Hutcheon AD, Norbury G, Mackenzie DI 2012. Predator control allows critically endangered lizards to recover on mainland New Zealand. New Zealand Journal of Ecology 36: 141-150.

Recio MR, Mathieu R, Maloney R, Seddon PJ 2010. First results of feral cats (Felis catus) monitored with GPS collars in New Zealand. New Zealand Journal of Ecology 34: 288-296.

Recio MR, Mathieu R, Virgós E, Seddon PJ 2014. Quantifying fine-scale resource selection by introduced feral cats to complement management decision-making in ecologically sensitive areas. Biological Invasions 16: 1915-1927.

Reid B 1967. Some features of recent research on the takahe (Notornis mantelli). Proceedings of the New Zealand Ecological Society 14: 79-87.

Reischek A 1884. Notes on New Zealand ornithology. Transactions of the New Zealand Institute 17: 187-198.

Richards AM 1972. Revision of the Rhaphidophoridae (Orthoptera) of New Zealand. Part XIV. Three alpine genera from the South Island. Journal of the Royal Society of New Zealand 2: 151-174.

Robertson C, Hyvönen P, Fraser M, Pickard C 2007. Atlas of bird distribution in New Zealand 1999-2004. Wellington, New Zealand, The Ornithological Society of New Zealand. $533 \mathrm{p}$.

Robertson H, Dowding J, Elliott G, Hitchmough R, Miskelly C, O’Donnell C, Powlesland R, Sagar P, Scofield P, Taylor G 2013. Conservation status of New Zealand birds, 2012. New Zealand Threat Classification Series 4. Wellington, New Zealand, Department of Conservation. 22 p.

Rolando A, Caprio E, Rinaldi E, Ellena I 2007. The impact of high-altitude ski-runs on alpine grassland bird communities. Journal of Applied Ecology 44: 210-219.

Rose A, Platt K 1987. Recovery of northern Fiordland alpine grasslands after reduction in the deer population. New Zealand Journal of Ecology 10: 23-33.

Rose A, Platt K 1992. Snow tussock (Chionochloa) population responses to removal of sheep and European hares, Canterbury, New Zealand. New Zealand Journal of Botany 30: 373-382.

Rudolph P 1999. Mustelid control and research. In: Beaven B, Harrison A, Shaw P eds. Northern Te Urewera ecosystem restoration project, Te Urewera National Park, Annual Report July 1997-June 1998. Gisborne, New Zealand, Department of Conservation. Pp. 39-63.

Ruscoe WA 2004. A new location record for kiore (Rattus exulans) on New Zealand's South Island. New Zealand Journal of Zoology 31: 1-5.

Ruscoe WA, Murphy EC 2005. House mouse. In: King CM ed. The handbook of New Zealand mammals. Melbourne, Oxford University Press. Pp. 204-222. 
Ruscoe WA, Wilson D, McElrea L, McElrea G, Richardson SJ 2004. A house mouse (Mus musculus) population eruption in response to rimu (Dacrydium cupressinum) seedfall in southern New Zealand. New Zealand Journal of Ecology 28: 259-265.

Sandercock BK, Martin K, Hannon SJ 2005. Life history strategies in extreme environments: comparative demography of arctic and alpine ptarmigan. Ecology 86: 2176-2186.

Sanders MD, Maloney RF 2002. Causes of mortality at nests of ground-nesting birds in the Upper Waitaki Basin, South Island, New Zealand: a 5-year video study. Biological Conservation 106: 225-236.

Saunders A, Norton D 2001. Ecological restoration at mainland islands in New Zealand. Biological Conservation 99: 109-119.

ScridelD 2014. Ecology and conservation of birds in upland and alpine habitats: a report on the BOU's Annual Conference held at the University of Leicester, 1-3 April 2014. Ibis 156: 896-900.

Simpkins C, Perry GL, Glaser A, Allerby T, Dennis TE 2015. Effects of predation by introduced mammals and mortality due to severe floods on population viability of the endangered blue duck (Hymenolaimus malacorhynchos). Emu 115: 146-157.

Smith DHV, Jamieson IG 2005. Lack of movement of stoats (Mustela erminea) between Nothofagus valley floors and alpine grasslands, with implications for the conservation of New Zealand's endangered fauna. New Zealand Journal of Ecology 29: 45-52.

Smith DHV, Jamieson IG, Peach RME 2005. Importance of ground weta (Hemiandrus spp.) in stoat (Mustela erminea) diet in small montane valleys and alpine grasslands. New Zealand Journal of Ecology 29: 207-214.

Smith DHV, Wilson DJ, Moller H, Murphy EC, van Heezik Y 2007. Selection of alpine grasslands over beech forest by stoats (Mustela erminea) in montane southern New Zealand. New Zealand Journal of Ecology 31: 88-97.

Smith DHV, Wilson DJ, Moller H, Murphy EC, Pickerell G 2008. Stoat density, diet and survival compared between alpine grassland and beech forest habitats. New Zealand Journal of Ecology 32: 166-176.

Smith DHV, Moller H, Wilson DJ, Murphy EC 2011. Prey switching by stoats (Mustela erminea): a supplemental food experiment. Wildlife Research 37: 604-611.

Stead E 1927. The native and introduced birds of Canterbury. In: Laing R, Speight R, Wall A eds. Natural history of Canterbury. Christchurch, Simpson and Williams. Pp. 204-225.

Studholme B 2000. Ship rat (Rattus rattus) irruptions in South Island beech (Nothofagus) forest. Wellington, New Zealand, Department of Conservation.

Tansell J 2009. Fiordland tokoeka chick recruitment study. Murchison Mountains 2003 to 2009. Unpublished report. Department of Conservation, Te Anau.

Tennyson AJ, Martinson P 2006. The extinct birds of New Zealand. Wellington, Te Papa Press. 180 p.

Tennyson AJ, Easton LJ, Wood JR 2014. Kea(Nestornotabilis) - another North Island human-caused extinction. Notornis 61: 174-176.

Tocher MD 2009. Life history traits contribute to decline of critically endangered lizards at Macraes Flat, Otago. New Zealand Journal of Ecology 33: 125-137.

Tompkins D, Gleeson D 2006. Relationship between avian malaria distribution and an exotic invasive mosquito in New Zealand. Journal of the Royal Society of New Zealand 36: 51-62.

Tompkins DM, Byrom AE, Pech RP 2013. Predicted responses of invasive mammal communities to climate-related changes in mast frequency in forest ecosystems. Ecological Applications 23: 1075-1085.

Towns DR, Daugherty CH 1994. Patterns of range contractions and extinctions in the New Zealand herpetofauna following human colonisation. New Zealand Journal of Zoology 21: $325-339$.

Trewick SA 2008. DNA barcoding is not enough: mismatch of taxonomy and genealogy in New Zealand grasshoppers (Orthoptera: Acrididae). Cladistics 24: 240-254.

Trewick SA, Morris SJ, Johns PM, Hitchmough RA, Stringer IA 2012. The conservation status of New Zealand Orthoptera. New Zealand Entomologist 35: 131-136.

van Riper III C, van Riper SG, Goff ML, Laird M 1986. The epizootiology and ecological significance of malaria in Hawaiian land birds. Ecological Monographs 56:327-344.

Walker KJ 2003. Recovery Plans for Powelliphanta Land Snails: 2003-2013. Wellington, New Zealand, Department of Conservation.

Wallis GP, Trewick SA 2009. New Zealand phylogeography: evolution on a small continent. Molecular Ecology 18: 3548-3580.

Weston K, Taylor S, Robertson B 2016. Identifying populations for management: fine-scale population structure in the New Zealand alpine rock wren (Xenicus gilviventris). Conservation Genetics 17: 691-701.

Wharton DA 2011. Cold tolerance of New Zealand alpine insects. Journal of Insect Physiology 57: 1090-1095.

Whitaker AH 1984. Hoplodactylus kahutarae n. sp.(Reptilia: Gekkonidae) from the Seaward Kaikoura Range, Marlborough, New Zealand. New Zealand Journal of Zoology 11: 259-270.

Whitaker AH 1987. The roles of lizards in New Zealand plant reproductive strategies. New Zealand Journal of Botany 25: $315-328$.

WhitakerAH 1997. The lizards of the Seaward Kaikoura Range. Proceedings of the Society for Research on Amphibians and Reptiles in New Zealand. New Zealand Journal of Zoology 24: 330-331.

Whitaker AH, Shaw T, Hitchmough RA 1999. Black-eyed geckos (Hoplodactylus kahutarae) on Mt Arthur, Kahurangi National Park. Conservation Advisory Science Notes 230. Wellington, Department of Conservation.

White EG 1975. A survey and assessment of grasshoppers as herbivores in the South Island alpine tussock grasslands of New Zealand. New Zealand Journal of Agricultural Research 18: 73-85.

WhiteheadAL, Edge K-A, SmartAF, Hill GS, Willans MJ 2008. Large scale predator control improves the productivity of a rare New Zealand riverine duck. Biological Conservation 141: 2784-2794.

Willans ML 2007. Rock wren abundance and predator impact study-McKenzie Burn, Murchison Mountains. Te Anau, New Zealand, Department of Conservation.

Willans M, Weston KA 2005. Translocation of rock wren Xenicus gilviventris from Murchison Mountains to Anchor Island, Dusky Sound, Fiordland. Te Anau, New Zealand, Department of Conservation.

Wilson DJ, Lee WG 2010. Primary and secondary resource pulses in an alpine ecosystem: snow tussock grass 
(Chionochloa spp.) flowering and house mouse (Mus musculus) populations in New Zealand. Wildlife Research 37: 89-103.

Wilson DJ, McElrea GJ, McElrea LM, Heyward RP, Peach RME, Thomson C 2006. Potential conservation impacts of high-altitude small mammals: a field study and literature review. DOC Research \& Development Series 248. Wellington, New Zealand, Department of Conservation.

Wong V, Hickling GJ 1999. Assessment and management of hare impact on high-altitude vegetation. Science for Conservation 16. Wellington, New Zealand, Department of Conservation.

Wood JR, Wilmshurst JM, Wagstaff SJ, Worthy TH, Rawlence NJ, Cooper A 2012. High-resolution coproecology: using coprolites to reconstruct the habits and habitats of New Zealand's extinct upland moa (Megalapteryx didinus). PLoS ONE 7: 1-13.

Worthy T 1987. Osteological observations on the larger species of the skink Cyclodina and the subfossil occurrence of these and the gecko Hoplodactylus duvaucelii in the North Island, New Zealand. New Zealand Journal of Zoology 14: 219-229.

Editorial board member: Deb Wilson

Received 25 July 2016; accepted 18 October 2016
Worthy T, Holdaway R 2002. Prehistoric life of New Zealand. The lost world of the moa. Bloomington, USA, Indiana University Press. 718 p.

Wotton DM, Drake DR, Powlesland RG, Ladley JJ 2016. The role of lizards as seed dispersers in New Zealand. Journal of the Royal Society of New Zealand 46: 40-65.

Ylönen H, Jacob J, Davies MJ, Singleton GR 2002. Predation risk and habitat selection of Australian house mice, Mus domesticus, during an incipient plague: desperate behaviour due to food depletion. Oikos 99: 284-289.

Young LM, Bell RJ 2010. Frugivory and primary seed dispersal by a New Zealand falcon (Falco novaeseelandiae) at Red Tarns, Mt Sebastapol, New Zealand. Notornis 57: 94-95.

Young LM, Kelly D 2014. Current rates of fruit removal and seed dispersal in New Zealand fleshy-fruited mountain plants. New Zealand Journal of Ecology 38: 288-296.

Young LM, Kelly D, Nelson XJ 2012. Alpine flora may depend on declining frugivorous parrot for seed dispersal. Biological Conservation 147: 133-142. 